MATUS, Jean Pierre "De nuevo sobre la falta de punibilidad de los atentados contra la libre competencia, de conformidad con el Art. 285 del Código penal. Algunos aspectos de la discusión con Héctor Hernández en Política Criminal"

Polít. crim. Vol. 8, № 15 (Julio 2013), Doc. 1, pp. 314 - 362.

[http://www.politicacriminal.cl/Vol_08/n_15/Vol8N15D1.pdf]

\title{
De nuevo sobre la falta de punibilidad de los atentados contra la libre competencia, de conformidad con el Art. 285 del Código penal. Algunos aspectos de la discusión con Héctor Hernández en Política Criminal
}

\author{
Dr. Jean Pierre Matus \\ Profesor Titular de Derecho Penal de la universidades de Chile y Finis Terrae \\ jpm@jpmatus.cl
}

\section{Introducción}

En este lugar se vuelve sobre algunos aspectos de la discusión esbozada en las páginas de Política Criminal entre Héctor Hernández ${ }^{1}$ y el suscrito, ${ }^{2}$ los cuales no pudieron abordarse adecuadamente en atención a que los textos confrontados fueron escritos de manera más $o$ menos simultánea.

Es por ello que se estudian aquí de nuevo algunos aspectos centrales que parecen ser el núcleo de la discusión, pero que no se encuentran explicitados en los textos de referencia, como la determinación del bien jurídico protegido o el concepto de precio natural, tratados en la primera parte del texto; o respecto de los cuales los textos enfrentados aparecen como una suerte de diálogo de sordos, dado el paralelismo de los argumentos empleados, como en lo que respecta a los efectos derogatorios de una ley posterior incompatible con la anterior en materias penales y la infracción potencial que la aplicación de una ley penal derogada supone frente al principio de legalidad, constitucionalmente consagrado, estudiados en la segunda parte.

No obstante, dado que el tema principal es el mismo, en más de algún argumento el lector podrá percibir una reiteración de lo que ya antes he expuesto en la materia. Sin embargo, creo que en esta nueva presentación, que confronta directamente los argumentos de Hernández con los míos propios, puede apreciarse mejor el mérito de las argumentaciones, por lo que ruego al lector excuse los momentos de deja-vù que la lectura de esta nueva contribución al tema le pueda deparar.

\footnotetext{
${ }^{1}$ HERNÁNDEZ B., HÉCTOR, "La punibilidad de la colusión (secreta) de precios en el derecho chileno", Política criminal No 13 (2012), pp. 147-167.

2 MATUS A., Jean Pierre, "Sobre la falta de punibilidad en Chile de los acuerdos de precios", Política Criminal No 14 (2012), pp. 318-356.
} 
MATUS, Jean Pierre "De nuevo sobre la falta de punibilidad de los atentados contra la libre competencia, de conformidad con el Art. 285 del Código penal. Algunos aspectos de la discusión con Héctor Hernández en Política Criminal"

\title{
1. Algunos aspectos de la tipicidad del delito del Art. 285 del Código penal, a la luz del bien jurídico protegido.
}

\subsection{Planteamiento del problema: El Art. 285 del Código penal de 1874 sanciona las infracciones a la libre concurrencia, no atentados a la libre competencia.}

El Código penal dispone:

\begin{abstract}
“Art. 285. Los que por medios fraudulentos consiguieren alterar el precio natural del trabajo, de los géneros o mercaderías, acciones, rentas públicas o privadas o de cualesquiera otras cosas que fueren objeto de contratación sufrirán las penas de reclusión menor en sus grados mínimo a medio y multa de seis a diez unidades".
\end{abstract}

Esta es, como señala don Eduardo Novoa, en el Código de 1874, una de las escasísimas disposiciones originales de dicho cuerpo normativo que regulan, junto con el delito de usura, un delito económico propiamente tal. ${ }^{3}$

Aunque no hay duda en la afirmación de Novoa, lo que se discute hoy en día es si dicha disposición es o no apta para la protección de los atentados contra la libre competencia, tras la expresa despenalización por la Ley $\mathrm{N}^{\circ} 19.911$, de 14 de noviembre de 2003, de los que se consideraban como tales en el Decreto Ley N 211 de 1974, actualmente bajo un régimen de sanciones administrativas impuestas por el Tribunal de la Libre Competencia, tras requerimiento de la Fiscalía Nacional Económica.

Así, nosotros hemos señalado que el texto del Art. 285 del Código penal de 1874 no sanciona los acuerdos de precios entre oferentes $\mathrm{u}$ otras atentados contra la libre competencia en la forma que hoy los concebimos, sino exclusivamente los agios o cualesquiera otras maniobras fraudulentas que afecten la libre concurrencia entre oferentes $y$ demandantes, provocando con ello una alteración del precio natural de las mercaderías, entendido como el que se acordaría entre ellos de no mediar dicho fraude.

En cambio, según Héctor Hernández el texto del Art. 285 del Código de 1874 sería plenamente aplicable hoy en día a supuestos propios de atentados contra la libre competencia, tales como los acuerdos (al menos los "secretos") entre oferentes, aunque tales acuerdos se hayan adoptado libremente, entendiendo que, en tal caso, desde el punto de vista de los demandantes dichos acuerdos serían "medios fraudulentos" en la relación comercial, los cuales tendrían como resultado una alteración del "precio natural" que entiende como el que resultaría de la "libre concurrencia", la cual identifica como "el libre juego de la oferta y la demanda, la libre competencia". 4

\footnotetext{
${ }^{3}$ NOVOA MONREAL, Eduardo, "La legislación penal económica", en: UNIVERSIDAD CATÓLICA DE CHILE. FACULTAD DE CIENCIAS JURÍDICAS, POLÍTICAS Y SOCIALES, La Nueva Legislación y el Desarrollo Económico de Chile. Ciclo de Conferencias, Julio-Septiembre, 1962. Santiago: Editorial Universidad Católica, 1962, 179 pp., pp. 151-177, p. 154.

${ }^{4}$ HERNÁNDEZ, “La punibilidad de la colusión”, cit. nota n ${ }^{\circ}$ 1, pp. 150-152 y 155. Hernández agrega que, además, de corresponder su propuesta al sentido del texto del Art. 285 Código penal, la despenalización expresa de las figuras relativas a la libre competencia no habría afectado la vigencia de éste a su respecto, "resurgiendo" o "volviendo a la vida" para ser aplicable también a los supuestos que hoy en día se encuentran
} 
Polít. crim. Vol. 8, No 15 (Julio 2013), Doc. 1, pp. 314 - 362.

[http://www.politicacriminal.cl/Vol_08/n_15/Vol8N15D1.pdf]

Como se aprecia, la cuestión de fondo en la disputa así resumida es si puede o no identificarse la libre concurrencia con la libre competencia y entenderlas ambas como bienes jurídicos protegidos por el Art. 285 del Código penal.

Si ello se admite, como propone implícitamente Hernández, entonces bien podría considerarse "precio natural" no sólo el que se fijaría en condiciones de libre concurrencia, esto es, del libre juego de la oferta y la demanda, sino también de libre competencia relativa entre oferentes; y estimarse como un "medio fraudulento" para alterarlo no sólo los engaños que afectan la libertad de los concurrentes a un mercado en un momento determinado, sino cualquier acuerdo, aunque sea libremente adoptado, de oferentes o demandantes sobre precios, cuotas de mercado u otras conductas monopolísticas.

Sin embargo, como se demostrará en este lugar, tales conclusiones son erradas, pues se fundamentan en una aparente confusión conceptual entre libre concurrencia y libre competencia. Esta confusión conceptual determina en Hernández una interpretación extensiva del Art. 285 del Código penal de 1874, una equivocada lectura de la historia fidedigna de su establecimiento y una parcial exposición de su interpretación por los autores, al punto de llegar a considerar, en la práctica, como superflua la regulación antimonopolios introducida en Chile el año 1959, precisamente para establecer sanciones penales a hechos que no se consideraban punibles hasta esa fecha.

1.1.1. La diferencia conceptual entre libre concurrencia y libre competencia. Consecuencias para la interpretación y la relación entre el Art. 285 del Código penal y la Ley N 13.035, de 1959 y las que le sucedieron, que sancionan los atentados contra la libre competencia.

Puesto que, como se ha dicho, el fondo de la disputa reseñada radica en admitir o no la propuesta de Hernández que confunde libre concurrencia con libre competencia, es necesario, para llegar al fondo del problema, aclarar los conceptos involucrados.

Según Valdés, aunque en la legislación reciente existen algunas normas que parecen no distinguir entre libre competencia y libre concurrencia, "desde una óptica doctrinaria, existe un matiz":

"La libre concurrencia requiere una estructura de mercado en la que participen pluralidad de oferentes, en tanto que la libe competencia opera toda vez que existe disputa entre dos o más personas que aspiran a obtener la misma cosa. De esta forma, si todas las personas que compiten en un determinado mercado relevante se conciertan

sancionados administrativamente. Sin embargo, este argumento no será abordado en este lugar, pues ya hemos expuesto detalladamente acerca de los errores conceptuales en que incurre Hernández al negar la aplicación a estos casos del texto expreso del Art. 52 del Código civil que establece la derogación tácita parcial como una forma de poner término a la vigencia de una norma legal anterior e incompatible con una posterior y aplicarle erróneamente la teoría del concurso aparente de leyes (que supone normas compatibles) olvidando las restricciones que al resurgimiento de las ley desplazada esa misma teoría ha desarrollado, a saber, la de no pasar a llevar adelante un privilegio claramente establecido, como lo es en la especie, la despenalización de tales conductas (MATUS, "La falta de punibilidad", cit. nota $\mathrm{n}^{\circ} 2$. Véase, además, mi Informe en Derecho sobre la inaplicabilidad por inconstitucionalidad del Art. 285 del Código penal a las conductas previstas y sancionadas administrativamente en el Decreto Ley $N^{o} 211$, reformado por la Ley $N^{o}$ 19.911, de 14 de noviembre de 2003”, 2012). 
MATUS, Jean Pierre "De nuevo sobre la falta de punibilidad de los atentados contra la libre competencia, de conformidad con el Art. 285 del Código penal. Algunos aspectos de la discusión con Héctor Hernández en Política Criminal"

para no competir entre sí, deja de haber libre competencia pero subsiste la libre concurrencia". 5

Luego, una conducta monopolística puede afectar la libre competencia, pero no afectará necesariamente la libre concurrencia.

Sin embargo, Hernández, desconociendo esta importante diferencia conceptual, cita a Valdés, para afirmar que el Art. 285 protegería también la libre competencia. ${ }^{6}$

No obstante, si se revisa el texto de Valdés citado por Hernández, se descubrirá que el primero sólo afirma, a propósito de la despenalización de las conductas monopólicas por medio de la Ley $\mathrm{N}^{\circ} 19.911$, lo siguiente:

"De esta forma desapareció el delito penal de monopolio contemplado en el Decreto Ley 211. No obstante lo anterior, es preciso advertir que aún subsisten delios penales contemplados en el Código Penal que guardan conexión con el bien jurídico tutelado libre competencia".

Nada más.

Desde luego, no se dice que el Art. 285 del Código penal sancione atentados contra la libre competencia, como para hacer una cita de autoridad en este punto; ni tampoco que los delitos subsistentes en el Código sancionen atentados contra la libre competencia, sino que "guardan relación" con ella.

Y, como acabamos de señalar, la libre concurrencia "guarda relación" con la libre competencia, pero son cosas diferentes: no puede haber libre competencia sin libre concurrencia, pero sí puede existir libre concurrencia sin libre competencia, en caso que los concurrentes, libremente, así lo decidan.

Esta diferencia conceptual explica por qué, al momento de promulgarse la Ley $\mathrm{N}^{\mathrm{o}} 13.305$, de 6 de abril de 1959, las autoridades y la doctrina estimaban entonces, sin lugar a dudas, que en su Art. 173 se estaba regulado penalmente, por primera vez, los atentados contra la libre competencia, afirmándose que así se venía a llenar un vacío necesitado de regulación, pues las conductas monopólicas no se consideraban sancionadas en el Código penal o en otras disposiciones especiales, como lo revela un estudio detallado de la historia de su establecimiento.

En efecto, en el Mensaje presidencial respectivo se señala que se pretende alcanzar el objetivo de aumentar la competencia y disminuir con ella los precios, "calificando de delito todo tipo de convenio o asociación que tienda a impedir la libre competencia", sin hacer siquiera mención a su potencial regulación anterior por el Código penal o a eventuales

\footnotetext{
${ }^{5}$ VALDÉS PRIETO, Domingo, Libre Competencia y Monopolio, Santiago: Ed. Jurídica de Chile, 2006 , p. 80.

${ }^{6}$ HERNÁNDEZ, “La punibilidad de la colusión”, cit. nota ${ }^{\circ} 1$, p. 159, nota 35.

${ }^{7}$ VALDÉS, Libre Competencia y Monopolio, cit. nota ${ }^{\circ}$ 5, p. 225 y s.
} 
Polít. crim. Vol. 8, № 15 (Julio 2013), Doc. 1, pp. 314 - 362.

[http://www.politicacriminal.cl/Vol_08/n_15/Vol8N15D1.pdf]

problemas prácticos para aplicar a tales hechos su artículo 285. Es más, este artículo no se menciona en ninguno de los ocho tomos de discusión legislativa. ${ }^{8}$

Por su parte en su discurso inaugural de las Quintas Jornadas de Ciencias Penales, el entonces Sr. Ministro de Justicia, don Enrique Ortúzar, señalaba que

"el actual Gobierno, en el convencimiento de la necesidad de proteger el orden público económico, patrocinó y obtuvo la dictación de una ley [el Título $\mathrm{V}$ de la Ley $\mathrm{N}^{\mathrm{o}}$ 13.305] que reprime los monopolios, delito inequívocamente de naturaleza económica". 9

Y el entonces Ministro de la Excma. Corte Suprema, don Eduardo Varas, explicaba que el Código penal se dictó bajo la premisa de que "los hombres actuaban libres" y que "el bien jurídico era el patrimonio de la víctima, amagado por medio de la estafa, de la usura y de la defraudación", castigando el artículo 285 del Código penal, sólo a los que "por medios fraudulentos" conseguían alterar los precios, por lo cual

"faltaba aún en Chile la represión de los monopolios y fue el actual Gobierno, en enero de 1959, el que deseoso de combatir las alzas injustificadas de precios y permitir en su integridad la libre competencia presentó al Parlamento el Proyecto de la Ley $\mathrm{N}^{\mathrm{o}}$ 13.305 [para] sancionar como delitos los acuerdos, pactos o convenciones que los particulares pudieran concertar, con el objeto de impedir la libre competencia". ${ }^{10}$

En contra de la consecuencia que de lo antes dicho es posible extraer, esto es, que el legislador nacional entendió necesario recién en 1959 sancionar los atentados contra la libre competencia, pues se estimaba que dichos atentados no se encontraban sancionados por el Código penal de 1874, cuyo Art. 285 se pensaba castigaba únicamente la alteración, por medios fraudulentos, de la libre concurrencia de los participantes en un mercado determinado, Hernández sostiene que:

"Extraer, sin embargo, conclusiones sobre los alcances de un precepto del Código penal exclusivamente a partir de la existencia de esta actividad legislativa implicaría desconocer por completo las prácticas del legislador chileno. Desde luego no habría sido ni la primera ni la última vez que se legislara sobre materias ya tratadas en el Código, sin derogar al mismo tiempo las disposiciones vigentes pertinentes [...] Por lo mismo, ni la Ley $\mathrm{N}^{\mathrm{o}} 13.305$ ni el DL $\mathrm{N}^{\mathrm{o}} 211$ pueden constituir argumento útil a la hora de determinar los alcances del art. 285, los que sólo pueden determinarse a partir de su propio tenor literal y de su historia fidedigna". ${ }^{11}$

Sin embargo, esta argumentación debe rechazarse por tres razones principales.

\footnotetext{
${ }^{8}$ Biblioteca del Congreso Nacional, Historia de la Ley $N^{o}$ 13.305. El Mensaje se encuentra en los Documentos de la Cuenta de la Sesión No 24, de 13.01.1959 de la Cámara de Diputados, y lo citado, en su p. 1316.

${ }^{9}$ ORTÚZAR, Enrique, "Discurso del acto inaugural de las Quintas Jornadas de Ciencias Penales", Revista de Ciencias Penales, T. XXI (1962), pp. 6-10, p. 9.

${ }^{10}$ VARAS, Eduardo, "Discurso del acto inaugural de las Quintas Jornadas de Ciencias Penales", Revista de Ciencias Penales, T. XXI (1962), pp. 10-16, pp. 11, 13 y 14.

${ }^{11}$ HERNÁNDEZ, "La punibilidad de la colusión", cit. nota nº 1, p. 158.
} 
MATUS, Jean Pierre "De nuevo sobre la falta de punibilidad de los atentados contra la libre competencia, de conformidad con el Art. 285 del Código penal. Algunos aspectos de la discusión con Héctor Hernández en Política Criminal"

Primero, porque no es sólo el hecho de una actividad legislativa posterior lo que se alega para sostener que el Art. 285 del Código penal de 1874 no contemplaba como bien jurídico la libre competencia, sino el que ésta se encontraba fundada expresamente en la necesidad de sancionar penalmente los hechos que la afectaban y que, a la fecha de su promulgación, se entendían no sancionados por el Código penal. Y ello, no por desconocimiento del Art. 285 de dicho cuerpo legal, sino porque se entendía que éste, conforme a su interpretación mayoritaria, no abarcaba los atentados contra la libre competencia, sino sólo aquellos que afectaban la libre concurrencia de los participantes en un mercado determinado.

En segundo lugar, porque la afirmación de que la interpretación del sentido y alcance de una figura legal "sólo" es posible "a partir de su propio tenor literal y de su historia fidedigna" es falsa, pues el mismo Código civil que dispone tales elementos interpretativos en su Art. 19, establece también, en su Art. 22, que, cuando el sentido de una ley no es claro,

“Art. 22. El contexto de la ley servirá para ilustrar el sentido de cada una de sus partes, de manera que haya entre todas ellas la debida correspondencia y armonía.

Los pasajes obscuros de una ley pueden ser ilustrados por medio de otras leyes, particularmente si versan sobre el mismo asunto".

Luego, si hemos de discutir sobre el sentido del texto del Art. 285 del Código penal más allá de su tenor literal (donde, recuérdese, no se mencionan expresamente los acuerdos de precios ni otras conductas monopolísticas como hechos típicos) no sólo habremos de discutir sobre lo que el legislador histórico intentó establecer, a través del estudio de las Actas correspondientes (el cual demuestra, por lo demás, que explícitamente no se quiso castigar las "coligaciones" para fijas precios), sino también sobre el sentido que en 1874 tendrían las expresiones medios fraudulentos y precio natural (particularmente, sus sentidos técnicos en la época), sino también sobre el que a ellas les ha ido dando el conjunto de la legislación en que se insertan, incluyendo la legislación posterior sobre materias relacionadas, de modo que, como manda el Código civil, se guarde la "debida correspondencia y armonía" entre los términos de la ley, entendiendo incorporados a ella sus epígrafes, títulos y subtítulos, otras leyes y demás reglas aplicables. ${ }^{12}$

Y esa debida armonía supone una adecuada delimitación del objeto de protección de unas y otras normas en juego, atendiendo su literalidad e historia, pero no de manera aislada, sino conjuntamente, lo cual nos permite ver con cierta claridad que, mientras el Art. 285 del Código penal de 1874 protegía y protege del fraude la libre concurrencia de los participantes en un mercado determinado; la legislación antimonopolio, en cambio, creada en Chile a partir del año 1959 con la Ley $\mathrm{N}^{\circ} 13.035$ protege la libre competencia entre oferentes o entre demandantes, concepto que, como ya hemos señalado, se diferencia del de libre concurrencia, pues puede existir libre concurrencia sin libre competencia, como cuando se producen acuerdos libres de precios entre oferentes, pero no a la inversa .

\footnotetext{
${ }^{12}$ Sobre el elemento sistemático en la interpretación, véase, con detalle MATUS A., Jean Pierre, La Ley Penal y su Interpretación, Santiago: Ed. Metropolitana, 2012, pp. 192 y ss.
} 
Polít. crim. Vol. 8, № 15 (Julio 2013), Doc. 1, pp. 314 - 362.

[http://www.politicacriminal.cl/Vol_08/n_15/Vol8N15D1.pdf]

Finalmente, la exclusión del análisis contextual que propone Hernández debe rechazarse porque lleva a conclusiones que se apartan de la realidad histórica de la evolución social y legislativa en Chile y en el mundo.

En efecto, por una parte, parece muy difícil aceptar que la Comisión Redactora del Código penal de 1874 se hubiese anticipado casi tres lustros a la primera ley penal reconocidamente antimonopolios en nuestra órbita cultural, la Sherman Act, que entró en vigor en los Estados Unidos de América el año 1890. Y por otra, la afirmación de que la legislación hispana decimonónica en que la nuestra se basó no contemplaba sanciones a las infracciones a libre competencia se puede comprobar también desde el punto de vista de la evolución histórica de la legislación española, pues allí la primera ley reconocidamente reguladora de la libre competencia fue establecida recién en 1963, bajo el número 110, y en cumplimiento de acuerdos con los Estados Unidos de América, precisamente porque existían monopolios y conductas monopólicas ("colusorias" y de "abuso de posición de mercado") que se entendían no reguladas suficientemente y que, por ello, debían sancionarse mediante una nueva normativa, la cual, como la chilena de 1959, fue también calificada de "sin precedentes en el ordenamiento jurídico español". 13

1.1.2. El argumento histórico. La labor de la Comisión Redactora del Código penal de 1874 y la expresa y consciente exclusión de los acuerdos libremente alcanzados entre oferentes como hechos punibles en el Art. 285 del Código penal.

Si se parte de la premisa a priori de que el Art. 285 del Código penal protegería la libre competencia, la conclusión lógica sería la afirmación de que en él se castigarían como medios fraudulentos para alterar el precio natural de las mercaderías, junto con los engaños como el agio, también los acuerdos libremente alcanzados entre oferentes para fijar precios, cuotas de mercado, distribución, etc., típicas conductas monopolísticas. Esta es la tesis de Hernández.

Pero Hernández sostiene que para llegar a esa conclusión no ha adoptado una premisa $a$ priori, sino que ella se fundamentaría en la historia del establecimiento del Ar. 285 del Código penal y en su literalidad, ofreciendo para ello los argumentos que enseguida pasamos a revisar.

Según Hernández, nuestra legislación se habría apartado "sutil pero significativamente del modelo del Código español de 1850", al eliminarse el ejemplo del esparcimiento de falsos rumores que en su Art. 462 antecedía a la frase "o usando cualquier otro artificio", reemplazando ambas expresiones por la escueta mención que hace referencia al empleo de "medios fraudulentos", añadiendo:

"La importancia del cambio radica en que, cualesquiera que hubiesen sido las razones subyacentes, al prescindirse de un ejemplo tan específico de medio fraudulento y, consiguientemente, de su potencial efecto heurístico restrictivo, la interpretación del artículo quedaba abierta para una enorme gama de posibilidades." 14

\footnotetext{
${ }^{13}$ ALCAIDE GALINDO, Cristina, "La evolución de la política de defensa de la competencia", Revista ICE $\mathrm{N}^{\circ} 826$ (2005), pp. 245-258.

${ }^{14}$ HERNÁNDEZ, “La punibilidad de la colusión”, cit. nota n 1 , p. 149.
} 
MATUS, Jean Pierre "De nuevo sobre la falta de punibilidad de los atentados contra la libre competencia, de conformidad con el Art. 285 del Código penal. Algunos aspectos de la discusión con Héctor Hernández en Política Criminal"

Luego, según Hernández, entre tales medios fraudulentos inespecíficos podrían comprenderse sin dificultad los acuerdos de precios libremente alcanzados entre oferentes, y especialmente las "colusiones (secretas)", casos que supuestamente no se encontrarían comprendidos en el texto español tomado como modelo dado el ejemplo "huerísticamente restrictivo" que contemplaba.

Sin embargo, este argumento debe rechazarse porque no es cierto, objetivamente, que el texto español de 1850, basado en el de 1848, contuviese la limitación a los medios fraudulentos que afectarían la libre concurrencia que supone Hernández, al darle un valor "huerísticamente restrictivo" al ejemplo de que se sirve el texto tomado como modelo por nuestra Comisión Redactora.

En efecto, el texto español tomado como modelo por el patrio disponía:

“Art. 462. Los que esparciendo falsos rumores, o usando de cualquier otro artificio, consiguieren alterar los precios naturales que resultarían de la libre concurrencia en las mercancías, acciones, rentas públicas o privadas, o cualesquiera otras cosas que fueren objeto de contratación, serán castigados con las penas de arresto mayor y multa de 100 a 1000 duros".

Una simple lectura del texto transcrito permite notar que éste, al contrario de lo que sugiere Hernández, no se encontraba limitado a sancionar el esparcir rumores falsos para alterar el precio de las mercaderías, sino que esta conducta se mencionaba como ejemplo meramente alternativo, no exclusivo ni taxativo, previo a la expresión genérica e inespecífica "o usando cualquier otro artificio". No dice el texto "artificio semejante", como hace nuestro Art. 468 para limitar los casos de estafa allí sancionados, ni añade ninguna expresión que permita llegar a la conclusión que sugiere Hernández en orden a que el ejemplo propuesto limitaría los medios fraudulentos, sino al contrario, literalmente se refiere a cualquier otro artificio.

No obstante, a pesar de la amplitud de la expresión "cualquier otro artificio", ningún autor español de relevancia, empezando por Pacheco desde el año 1848 hasta la modificación del texto en el Código de 1995, creyó ver en esta figura un tipo penal que sancionase ampliamente las conductas monopólicas. ${ }^{15}$

Luego, no puede aceptarse que sea la mayor o menor amplitud de las expresiones otros artificios o medios fraudulentos la que permita comprender como un bien jurídico protegido en estas figuras la libre competencia.

Al contrario, el legislador español, como demuestra los ejemplos propuestos por Pacheco (miembro de la Comisión Redactora peninsular del Código de 1848), tenía en mente que tales artificios no consistían en acuerdos libremente alcanzados entre oferentes y

\footnotetext{
${ }^{15}$ Es más, el Código penal de 1995 “concreta las conductas tipificadas a diferencia de lo que hacía el C.p. derogado, como son la difusión de noticias falsas, empleando violencia, amenaza o engaño", eliminándose la expresión "cualquier otro artificio" del texto de 1848 (SERRANO GÓMEZ, Alfonso; SERRANO MAÍLLO, Alfonso, Derecho penal, parte especial, 12 ${ }^{a}$ edición. Madrid: Dykinson 2007, 1186 pp., p. 513).
} 
Polít. crim. Vol. 8, № 15 (Julio 2013), Doc. 1, pp. 314 - 362.

[http://www.politicacriminal.cl/Vol_08/n_15/Vol8N15D1.pdf]

demandantes, sino en maquinaciones que afectan la libre concurrencia de oferentes y demandantes, llevando a unos y otros a creer en condiciones que impactarán en la escasez o abundancia inmediata o futura de ciertas mercaderías, lo cual alteraría el precio que por ellas se habría acordado sin mediar dicho fraude o artificio, es decir, libremente. Por eso es que al comentar el Art. 451 del Código de 1848, que pasaría sin modificaciones a ser el 462 del de 1850, explicaba Pacheco el delito en cuestión con estos ejemplos, que corresponden a la idea genérica del agio, propia del siglo XIX, y no de los atentados a la libre competencia, como se comprenderían en el siglo siguiente:

"Una carta falsa leida en la Bolsa, un posta simulado que se haga entrar ostensiblemente para divulgar cierta noticia, un anuncio hábil inserto en un periódico, pueden en determinadas circunstancias causar un trastorno en los precios que enriquezca y arruina á mil personas". ${ }^{16}$

1.1.3. La explícita exclusión de los acuerdos de precios ("coligaciones") que los miembros de la Comisión Redactora del Código penal de 1874 expresaron en las modificaciones al texto tomado del modelo español.

Como ya hemos señalado, el origen del artículo 285 de nuestro Código penal se encuentra en los artículos 461 y 462 del Código penal español de 1850, disposiciones idénticas a las contempladas en los artículos 450 y 451 del Código español de 1848, cuyas concordancias refiere Pacheco a la Ley 2, Titulo 7, Partida V, que castigaba con destierro, comiso y una multa a favor del Rey el "coto" que ponían los acuerdos de precios de mercaderías y del trabajo no autorizados por éste; a los artículos 414 a 419 del Código francés de 1810, y a las disposiciones de los artículos 227 a 229 del Código austríaco. ${ }^{17}$

Si se analizan las disposiciones a las que se remiten las concordancias, descontado el régimen de las Partidas, su principal particularidad es que en ellas se hacía una distinción más o menos clara entre tres conductas diferentes: los acuerdos o "coligaciones" para determinar el precio del trabajo (tanto por empleadores como por trabajadores); la "coligaciones" para fijar el precio de las mercaderías; y el empleo de medios fraudulentos para alterar el precio natural de las mercaderías.

Así, según transcribe el citado Pacheco, el Código francés castigaba separadamente la coligación "entre los que tengan trabajadores a su servicio" (artículo 414), de la realizada por los propios trabajadores (artículo 416); y ambas de "la coligación entre los principales tenedores de una misma mercancía o artículo formada para no venderla, o venderla solo a cierto precio" (artículo 419, primera parte), y de la divulgación de hechos falsos y la actuación "por otras vías o medios fraudulentos", que "hicieren subir o bajar el precio de géneros, mercancías, documentos o efectos públicos, en más o menos suma de la que hubiere resultado de la libre concurrencia del comercio" (Art. 419, segunda parte). Por su parte, aunque el Código austríaco describía como "infracción de policía" en un solo artículo "el concierto entre algunos o todos los individuos de una profesión para hacer subir o bajar en provecho propio y en perjuicio del público el precio de una mercancía o trabajo"

\footnotetext{
${ }^{16}$ PACHECO, Joaquín Francisco, El Código penal concordado y comentado, t. III, Madrid: Imp. Santiago Saunaque, 1849,500 pp., p. 387.

${ }^{17}$ PACHECO, El Código penal III, cit. nota n 16 , pp. 384 y ss.
} 
MATUS, Jean Pierre "De nuevo sobre la falta de punibilidad de los atentados contra la libre competencia, de conformidad con el Art. 285 del Código penal. Algunos aspectos de la discusión con Héctor Hernández en Política Criminal"

(artículo 227, parte final), castigaba con diferentes penas las "coligaciones de obreros artesanos" (artículo 229), de las restantes (artículo 228).

Sin embargo, al redactarse el Código español de 1848, de los tres casos previstos en las legislaciones que sirvieron de antecedente, esto es, la coligación para fijar los precios del trabajo, la coligación para fijar los precios de las mercaderías, y el empleo de medios fraudulentos para alterar su precio natural, sólo aparecieron expresamente recogidos el primero y el último.

En efecto, mientras el artículo 450 del texto hispano castigaba a "los que se coligaren con el fin de encarecer o abaratar abusivamente el precio del trabajo, o regular sus condiciones"; el 451 lo hacía respecto de "los que esparciendo falsos rumores, ó usando de cualquier otro artificio, consiguieren alterar los precios naturales que resultarían de la libre concurrencia en las mercaderías, acciones, rentas públicas ó privadas, ó cualesquiera otras cosas que fueren objeto de contratación".

Por lo mismo, omite mencionar Pacheco en sus Comentarios la posibilidad de que el artículo 451 contemplase también la "coligación efectiva" para fijar los precios de las mercaderías diferentes al trabajo, caso expresamente contemplado en el Código francés y en el austríaco, tenidos a la vista y transcritos en el Comentario respectivo. ${ }^{18}$

Por lo tanto, ya en el texto hispano tomado como modelo por nuestra Comisión Redactora se había excluido la tipificación como delito el supuesto paradigmático de atentado contra la libre competencia, esto es, el caso de la "coligación" para fijar precios de las mercaderías, quedando sólo como punibles las "coligaciones" efectivas de trabajadores o empresarios para fijar el precio del trabajo.

Como es sabido que nuestra Comisión Redactora tenía a la vista los Comentarios de Pacheco, lo más natural sería que, si se hubiese querido legislar en el mismo sentido que el Código francés o el austríaco, castigando también las coligaciones para fijar el precio de las mercaderías, se hubiese hecho expresamente, pues para ello hubiese bastado con transcribir el texto francés, que se tenía a la vista.

Pero esto no sucedió al discutirse el texto nacional, sino que ocurrió otra cosa diferente, que ratifica la intención del legislador patrio de 1874 de no castigar por la vía del Art. 285 del Código penal las coligaciones o acuerdos libremente alcanzados entre oferentes o entre demandantes, esto es, lo que hoy llamaríamos un atentado contra la libre competencia, sino únicamente los fraudes que afectan la libre concurrencia de oferentes y demandantes en un mercado determinado, al suprimirse explícitamente del texto proyectado el castigo de las "coligaciones" para fijar el precio del trabajo y la regla que sancionaba la "coligación" para alterar los bienes de primera necesidad desde el momento mismo que comenzaba a ejecutarse.

${ }^{18}$ PACHECO, El Código penal III, cit. nota n 16, p. 387. 
Polít. crim. Vol. 8, № 15 (Julio 2013), Doc. 1, pp. 314 - 362.

[http://www.politicacriminal.cl/Vol_08/n_15/Vol8N15D1.pdf]

En efecto, como señala Fuenzalida, "en la primera redacción del proyecto de nuestro código se había aprobado un artículo que penaba, como el 461 del Código Español, a la coligaciones para encarecer o abaratar abusivamente el precio del trabajo o regular sus condiciones". 19

En la misma sesión en que se aprobó dicho artículo ( $\mathrm{N}^{\circ}$ 61, de 13 de octubre de 1871), se tomó, "con alguna modificación en cuanto a la pena", ${ }^{20}$ del artículo 462 Código penal español de 1850 [451 del texto de 1848] la primera redacción del que llegaría a ser nuestro actual artículo 285, entonces numerado como 276 en el Proyecto:

“Artículo 276. Los que por cualesquiera medios fraudulentos consiguieren alterar el precio natural de los jéneros, mercancías, acciones, rentas públicas o privadas, o cualesquiera otras cosas que fueren objeto de contratación, sufrirán las penas de reclusión menor i multa". ${ }^{21}$

En cuanto a este artículo, ya hemos discutido en el apartado anterior el sentido del cambio de redacción operado en su encabezado, por lo que a él nos remitimos.

Lo que interesa es este lugar es señalar que, en dicha sesión, además se aprobó sin mayor discusión la figura agravada del entonces proyectado artículo 277 y que hoy corresponde al artículo 286 del vigente Código penal. Esta figura agravada contemplaba dos incisos, en el primero de los cuales se reafirmaba el carácter fraudulento de las conductas sancionados en la figura general, agregando el segundo, sin embargo, una disposición particular en la cual parecía asimilarse la "coligación" fraudulenta para fijar precios con alguno de los medios fraudulentos de que hablaba la disposición general. Así, este entonces proyectado artículo 277 disponía:

“Artículo 277. Cuando el fraude espresado en el artículo anterior recayere sobre mantenimientos u otros objetos de primera necesidad, ademas de las penas que en él se señalan, se impondrá la de comiso de los jéneros que fueren objeto del fraude.

Para la imposición de estas penas, bastará que la coalición haya empezado a ejecutarse."

Sin embargo, durante la "revisación" del proyecto de Código, en la sesión 156 de 17 de junio de 1873, "el señor Gandarillas [quien había sido Ministro de Hacienda de Pérez] manifestó que no creía justa la subsistencia del artículo 276 [275] del proyecto, porque no era posible castigar el uso legítimo de un derecho, como es el que cada cual tiene para determinar el precio de su trabajo", entendiéndose como tal "uso legítimo" la "coligación" o acuerdo para fijarlo, pues por "coligados" que estén los oferentes o los demandantes, "en esta materia no debe admitirse otro regulador o correctivo que la misma libertad de

\footnotetext{
${ }^{19}$ Ver, por todos, FUENZALIDA, Alejandro, Concordancias i Comentarios del Código penal chileno, t. II. Lima: Imp. Comercial Calle del Haullaga N. 139, 1883, 372 pp., p. 300.

${ }^{20}$ FERNÁNDEZ, Pedro Javier, Código penal de la República de Chile, explicado i concordado. Segunda Edición notablemente aumentada i corregida, t. II, Santiago: Imp. Barcelona, 1900, 410 pp., p. 33.

${ }^{21}$ Actas de las sesiones de la Comisión Redactora del Código penal chileno. Santiago: Imp. De la República de Jacinto Nuñez, 1873, 314 pp. encuadernadas junto al Proyecto de Código penal Chileno, de la misma imprenta y año, p. 120.
} 
MATUS, Jean Pierre "De nuevo sobre la falta de punibilidad de los atentados contra la libre competencia, de conformidad con el Art. 285 del Código penal. Algunos aspectos de la discusión con Héctor Hernández en Política Criminal"

industria, ${ }^{22}$ de la cual solamente puede resultar una fijación equitativa de los valores". Por estas consideraciones, estimó la Comisión Redactora que "lo único que merece castigo es el empleo de medios fraudulentos para abaratar o encarecer el precio del trabajo", y se suprimió el proyectado artículo 276 [275] y en el siguiente [antes aprobado como 276] se incorporó el trabajo entre los objetos cuyo precio podría alterarse fraudulentamente, alterándose nuevamente la pena. Además, se suprimió el inciso segundo del proyectado Art. $277^{23}$

En consecuencia, la intención expresa del legislador, manifestada en la supresión de un artículo y una agravación que hacía referencia a la "coligación" para fijar el precio de ciertas mercaderías era señalar que los acuerdos de precios entre oferentes o demandantes del trabajo y de cualquier otra mercadería no serían punibles, porque al alcanzarlos, los participantes ejercitaban sus derechos, esto es, su libertad contractual. Sólo cuando se alterase dicha libertad mediante un medio fraudulento se podría entender cometido el delito.

Pero, según Hernández, del hecho de que nuestra Comisión Redactora haya admitido explícitamente la libertad para acordar los precios del trabajo, afirmando sin lugar a duda alguna la licitud de las coligaciones de empresarios y trabajadores para fijar los precios de los salarios, no puede derivarse que todo acuerdo entre productores o demandantes libremente alcanzado se considerase lícito, pues

"eso implicaría pasar por alto el objeto preciso y el status peculiar de lo tratado en el artículo suprimido, referido exclusivamente a la libertad de asociación, tanto sindical como patronal, y su influencia en el precio de un factor económico específico, como era el trabajo". ${ }^{24}$

Este argumento debe, sin embargo, rechazarse, por las siguientes razones:

\footnotetext{
${ }^{22}$ La expresión libertad de industria se entendía en aquella época como uno de los derechos garantidos por la Constitución de 1833, cuyo artículo 151 disponía: "Ninguna clase de trabajo o industria puede ser prohibida, a menos que se oponga a las buenas costumbres, a la seguridad, o a la salubridad, o que lo exija el interés nacional, y una ley lo declare así". En palabras de Manuel CARRASCO ALBANO, este artículo "garantiza el derecho sagrado de todo hombre a la libre aplicación de sus facultades físicas e intelectuales sobre las fuerzas naturales para su propio bienestar y comodidad, que se llama libertad de industria" (Valparaíso, Imp. El Mercurio, 1858, pp. 225 y ss). Es decir, se trata de una garantía que suponía la no intervención del Estado poniendo trabas o limitaciones en la creación y participación de industrias y mercados a quienes desearen hacerlo. Sobre la base de este concepto, la intervención de Gandarillas que la Comisión hizo suya se puede interpretar de la siguiente manera: existiendo libertad de industria, o lo que es igual, no existiendo trabas para el ingreso de oferentes y demandantes en un mercado determinado, las coligaciones o acuerdos de precios o de otra naturaleza entre oferentes o entre demandantes, si se han alcanzado libremente, no afectarán el precio de las cosas, pues siempre existirá la posibilidad de que otro oferente u otro demandante ingrese al mercado y oferte un precio que los demandantes u oferentes estén dispuestos libremente a aceptar, en tanto su libre concurrencia no sea alterada fraudulentamente. Luego, sólo si media un fraude que afecta al mercado como tal, esto es, al conjunto de oferentes y demandantes en un momento determinado, se afectará la libre concurrencia y el autor del engaño deberá ser sancionado.

${ }^{23}$ Actas, cit. nota $\mathrm{n}^{\circ} 21$, p. 280.

${ }^{24}$ HERNÁNDEZ, "La punibilidad de la colusión”, cit. nota n ${ }^{\circ}$, p. 151.
} 
En primer lugar, porque al afirmarse que las modificaciones propuestas por Gandarillas se basarían en un supuesto "status particular" de las relaciones laborales, se introduce una consideración carente de fuente de respaldo. Nada en las Actas de la Comisión Redactora sugiere esta idea. Es más, la redacción final del Art. 285 sugiere todo lo contrario, al quedar las relaciones laborales enumeradas sin distinción alguna con los otros "factores económicos", como "los géneros o mercaderías, acciones, rentas públicas o privadas" "o cualesquiera otras cosas que fueren objeto de contratación". Es decir, la objetiva voluntad del legislador, coincidente con la de los miembros de la Comisión Redactora, fue considerar al trabajo como una más entre las "cosas que fueren objeto de contratación", y no establecer una especial regulación para la libertad de asociación en el ámbito laboral. Y si Hernández admite, porque así es claro en la historia de la ley, que las coligaciones para fijar el precio del trabajo son lícitas, siendo en aquella época el trabajo una especie más de cosa objeto de contratación, no hay ninguna razón legal ni histórica para suponer que respecto del resto de dichas cosas o "factores" como les llama Hernández, esa coligación se considerase ilícita, pues la ley no hace ninguna distinción al respecto.

Es más, Hernández no menciona que junto con incorporar al trabajo dentro de los objetos de contratación, declarando lícitos los acuerdos de precios entre trabajadores y empresarios, la Comisión acordó, "a consecuencia de esta alteración" suprimir el anteriormente aprobado inciso segundo del proyectado Art. 277 y que pasaría a ser en definitiva el actual Art. 286, y que castiga el caso agravado que se refiere a la alteración de precios de bienes de primera necesidad. Como dijimos, dicho inciso segundo disponía que "para la imposición de estas penas, bastará que la coalición haya empezado a ejecutarse". Luego, como este inciso no se refería a las relaciones laborales ni a su supuesto status diferenciado, sino a toda alteración de precios de ciertas mercancías por medios fraudulentos, su derogación es consecuencia no del status especial del trabajo, sino de la intención claramente manifestada de la Comisión Redactora, aceptando el planteamiento de Gandarillas, en orden a no sancionar las coligaciones o acuerdos de precios entre productores de bienes, incluso tratándose de bienes de primera necesidad.

En consecuencia, la explícita admisión por parte de la Comisión Redactora de la licitud de las coligaciones para fijar los precios del trabajo y de los otros objetos de contratación sólo puede ser comprensible si se considera que en estos artículos el legislador no castiga un atentado contra la libre competencia, sino un atentado contra la libre concurrencia, esto es, el agio y el resto de los fraudes que permiten alterar el precio natural de las cosas, engañando al conjunto del resto de los participantes del mercado que se trate. ${ }^{25}$

1.1.4. La doctrina posterior. Consenso general en torno a la inexistencia de un delito monopólico en el Art. 285 del Código penal, que castigase cualquier clase de acuerdos entre productores, hasta antes de la promulgación de la Ley $\mathrm{N}^{\mathrm{o}} 13.305$, de 6 de abril de 1959.

\footnotetext{
${ }^{25}$ Esta idea del engaño simultáneo a un conjunto de individuos, afectando con ello la libre concurrencia, es lo que diferencia esta clase de fraudes de los de las estafas y otros engaños de los Arts. 467 y siguientes del Código penal, y determina el carácter de bien jurídico colectivo que tiene, en el Art. 285, la libre concurrencia de ofertantes y demandantes, pues, reiterando las palabras de Pacheco (ob. y loc. cit.), un engaño colectivo como el agio puede "en determinadas circunstancias causar un trastorno en los precios, que enriquezca y arruine a miles de personas"
} 
MATUS, Jean Pierre "De nuevo sobre la falta de punibilidad de los atentados contra la libre competencia, de conformidad con el Art. 285 del Código penal. Algunos aspectos de la discusión con Héctor Hernández en Política Criminal"

Como señala el citado Novoa, la reducción del ámbito de lo punible por parte de nuestra Comisión Redactora, en la forma antes explicada, es apropiada a la mentalidad de los redactores del Código y su época, pues

"es perfectamente explicable que quienes partían de una supuesta igualdad entre las partes contratantes en cualquier tipo de negocio, consideraran ilícito solamente el valerse de maquinaciones dolosas (fraudes) para inducir a error a otro contratante y hacerlo caer así en un vicio del consentimiento",

pero el que actuaba "sin fraude y sin error", "no podía quedar sujeto a sanción", y por lo tanto, "el artículo 285 ya citado pena únicamente a los que alteran los precios naturales (...) valiéndose de medios fraudulentos". ${ }^{26}$

En el mismo sentido, Luis Cousiño M. afirmaba que "basta un análisis superficial” de los delitos contemplados en el párrafo $7^{\circ}$ del Título VI del Libro II del Código penal (entre ellos, el del artículo 285),

"para advertir que su objeto jurídico está radicado en los intereses particulares —no públicos- del industrial, del contratante o del dueño de la empresa subastada, sin que los prive de esta calidad la circunstancia de que en el artículo 286 se contenga una pena accesoria si la alteración del precio natural 'recayere en mantenimientos $\mathrm{u}$ otros objetos de primera necesidad', porque el eje sobre el cual giran los varios preceptos es el fraude, esto es, el perjuicio sufrido mediante engaño, abuso de confianza o incumplimiento doloso y no la naturaleza socioeconómica de dichos objetos de primera necesidad". ${ }^{27}$

En consecuencia, la doctrina más autorizada en materia económica del Siglo XX no dudaba en afirmar la necesidad de la existencia de un medio fraudulento como requisito básico para la configuración del delito del Art. 285 del Código penal, única forma de afectar la libre concurrencia en el mercado, pues la libre competencia no se entendió penalmente protegida sino hasta la entrada en vigor de la ley No 13.305, del año 1959.

Contra esta doctrina, dominante y pacífica hasta bien entrado el siglo XX, Hernández plantea ahora que si se atiende únicamente a la expresión "medios fraudulentos" y se le otorga el sentido amplio que propone, el Art. 285 del Código penal de 1874 comprendería también el castigo de atentados contra la libre competencia como los acuerdos de precios o mercado entre oferentes, incluso si se han alcanzado libremente.

Ya hemos visto que la interpretación de Hernández no corresponde al sentido del texto legal, que hace referencia a medios fraudulentos y no a acuerdos libremente concertados, los cuales, según la historia fidedigna de su establecimiento son lícitos, un simple ejercicio de la libertad de contratación que no puede ser sancionado si no ha mediado fraude o coacción. También hemos señalado que esta interpretación, que especifica el bien jurídico

\footnotetext{
${ }^{26}$ NOVOA, "La legislación penal económica", cit. nota ${ }^{\circ} 3$, p. 155.

${ }^{27}$ COUSIÑO M., Luis, "El delito socioeconómico", Revista de Ciencias Penales T. XXI (1962), pp. 47-63, pp. 48-50, 59 y ss.
} 
Polít. crim. Vol. 8, № 15 (Julio 2013), Doc. 1, pp. 314 - 362.

[http://www.politicacriminal.cl/Vol_08/n_15/Vol8N15D1.pdf]

protegido como la libre concurrencia es concordante no sólo con la distinción teórica entre libre competencia y libre concurrencia, sino también con el conjunto de la legislación y su evolución histórica, que en el ámbito hispano vino a sancionar los atentados contra la libre competencia sólo después de la mitad del siglo XX, entre nosotros, con la entrada en vigor de la Ley $\mathrm{N}^{\circ}$ 13.305, de 1959.

Sin embargo, Hernández plantea que su interpretación extensiva del sentido de la expresión "medios fraudulentos" no sería aislada ni novedosa y que ella tendría antecedentes en otros autores, empezando por Alejandro Fuenzalida, nuestro primer comentarista, que habrían llegado a similares conclusiones. ${ }^{28}$

Sin embargo, si se lee el texto completo de Fuenzalida, puede verse que es cierto que éste se refiere al Art. 419 del Código francés, pero en un contexto en que se parte por aceptar la licitud de los acuerdos entre oferentes de trabajo por el uso que en ellos se supone de la libertad, "aunque tengan por objeto una baja irregular i forzada de los salarios", y sin declarar expresamente que nuestro Art. 285 castigue otros acuerdos de precios, pues no parece que pueda sostenerse coherentemente que en unos casos el mismo uso de la libertad sea lícito y en otros no. Ello explica que en la cita completa del párrafo donde Fuenzalida cita el Código francés no se haga referencia a los acuerdos de precios o de mercado como medios fraudulentos para alterar el precio de las mercaderías, sino únicamente se diga lo siguiente:

"Por lo demás, el art. 419 del Código Penal de Francia nos suministra ejemplos de medios fraudulentos que pueden usarse para hacer subir o bajar el precio natural de los salarios, jéneros, mercadería, etc. <<divulgar de intento entre el pueblo hechos falsos i calumniosos o hacer ofertas ficticias a los mismos vendedores $>>$ ". ${ }^{29}$

Tampoco se puede citar a Fernández para afirmar que éste consideraba los acuerdos entre productores como una forma de cometer este delito, en circunstancias que dicho autor, para ejemplificar los medios fraudulentos emplea las mismas palabras de Pacheco aquí antes citadas ("una carta falsa, leída en la Bolsa, un posta simulado que se haga entrar ostensiblemente para divulgar cierta noticia, etc."), graficando este último caso precisamente con el del "posta" falso que en 1814, vestido de oficial de Marina inglesa, divulgó - aparentando desembarcar desde Francia- la falsa noticia de una victoria Aliada y la muerte de Napoleón a las puertas de París, lo cual significó primero una enorme ganancia para los tenedores de títulos del Gobierno Inglés, entre los que se contaba la familia y el propio Lord Cochrane, y luego, su procesamiento y condenada por haber recibido en su casa al falso oficial de Marina, quien allí se cambió de ropa para no ser descubierto. ${ }^{30}$

Por otra parte, tampoco parecen apoyar las afirmaciones de Hernández el profesor Del Río, para quien este delito puede cometerse por "todos los medios conducentes a las resultantes

\footnotetext{
${ }^{28}$ HERNÁNDEZ, "La punibilidad de la colusión”, cit. nota nº 1 , pp. 152 y ss.

${ }^{29}$ FUENZALIDA, Concordancias $i$ Comentarios, cit. nota ${ }^{\circ} 19$, p. 301.

${ }^{30}$ FERNÁNDEZ, Código penal de la República de Chile, cit. nota n² 20, pp. 34 y ss. Según este autor, el suceso habría servido para que Cochrane se decidiese a participar en nuestra Guerra de Independencia, y con el tiempo, se habría también demostrado su inocencia, pues habría sido, al parecer, utilizado por el "posta” y sus compinches, aprovechándose de una deuda de Cochrane con éste.
} 
MATUS, Jean Pierre "De nuevo sobre la falta de punibilidad de los atentados contra la libre competencia, de conformidad con el Art. 285 del Código penal. Algunos aspectos de la discusión con Héctor Hernández en Política Criminal"

previstas en la ley", siempre que sean "medios fraudulentos", y "por fraudulento debe entenderse todo procedimiento engañoso o falaz", como

"las maquinaciones capaces de turbar las condiciones normales de un mercado, impidiendo la regulación automática de los valores por la ley de la oferta y la demanda y obteniendo una regulación ficticia por medio de ofertas y demandas irreales". ${ }^{31}$

Y menos Labatut, quien parte por afirmar lo que hasta aquí se ha dicho, esto es, que esta figura está "basada en la libertad de contratación", y que tendría la amplia "finalidad de asegurar el libre juego de la oferta y la demanda, e impedir las alzas o bajas injustificadas del precio de la mano de obra y de las cosas comerciales", reduciendo su tipicidad a lo que en el texto legal se prevé, esto es, a su comisión por medios fraudulentos, que "pueden consistir en la difusión de rumores o noticias falsos, en el acaparamiento anormal de determinadas mercaderías, etc." 32

Mucho menos parece de recibo querer hacer decir a Etcheberry lo que no dice cuando afirma que

"como puede advertirse de su tenor y de los antecedentes históricos (...), nuestro legislador tenía el convencimiento de que de la libre concurrencia no podía sino resultar siempre el precio equitativo o natural de las cosas, incluido el trabajo entre estas últimas",

de lo cual se concluye que

"la expresión medios fraudulentos comprende cualesquiera artificios engañosos, como esparcir falsos rumores u otra conducta semejante al agio: hacer variar los precios del mercado de manera artificial y con engaño para lucrar de ello". ${ }^{33}$

Sólo dos autores pueden ser citados en apoyo de la tesis de Hernández: Robustiano Vera y Florencio Bañados. Pero es conocida la afición de Vera de transcribir como propios comentarios del texto español, y ello explica que escriba que el artículo 285 "estima delito toda coligación, sea de empresarios o bien de operarios para forzar en un sentido o en otro el curso libre del trabajo i su precio natural, así como el de los jéneros o mercaderías, acciones, rentas públicas o privadas", ${ }^{34}$ a pesar de que -como hemos visto- en el texto chileno no se castigase la coligación para fijar el precio del trabajo. Y la cita de Florencio Bañados parece incurre en el mismo error de Vera, esto es, leer algún comentario francés o español y hacer de su transcripción un cometario del Código chileno, sin atender a la

\footnotetext{
${ }^{31}$ DEL RÍO, J. Raimundo, Derecho penal. Tercer tomo. Santiago: Nascimento, 1935, 580 pp., p. 242.

${ }^{32}$ LABATUT, Gustavo, Derecho penal, Tomo II, parte especial. Séptima edición. Actualizado por el profesor Julio ZENTENO. Santiago: Editorial Jurídica de Chile, 1996, 263 pp., p. 107.

${ }^{33}$ ETCHEBERRY, Alfredo, Derecho penal, parte especial, t. IV. Tercera edición revisada y actualizada. Santiago: Ed. Jurídica de Chile, 1998, 382 pp., p. 280.

${ }^{34}$ VERA, Robustiano, Código penal de la República de Chile, comentado. Santiago: Imprenta de P. Cadot i Cía., 1883, 840 pp., p. 483.
} 
Polít. crim. Vol. 8, № 15 (Julio 2013), Doc. 1, pp. 314 - 362.

[http://www.politicacriminal.cl/Vol_08/n_15/Vol8N15D1.pdf]

historia de la legislación ni a su texto, al ejemplificar como un caso punible de trust el de un comerciante ¡francés! linchado por hacer subir el precio del azúcar. ${ }^{35}$

En definitiva, contra la opinión de Hernández en el sentido que el bien jurídico protegido en esta figura sería la libre competencia, ${ }^{36}$ la mejor y mayoritaria doctrina nacional ha sido consistente en afirmar que el bien jurídico protegido por el Art. 285 del Código penal es otro: la libre concurrencia entre los participantes en el mercado, y que el modo de ataque típicamente relevante es el fraude que permite alterar la voluntad, engañando a oferentes y demandantes para que éstos acuerden a un precio diferente al que habrían acordado de no concurrir el fraude. De donde se sigue que los acuerdos de precios, en la medida que se adoptan libremente por los concurrentes al mismo, esto es, sin que medie fraude o engaño, no se consideran como hechos que puedan calificarse de típicos, de conformidad con el Art. 285 del Código penal, pues en ellos no se afecta la libre concurrencia, su bien jurídico u objeto de protección, sin perjuicio de su calificación por los organismos encargados de velar por la libre competencia como atentatorios contra este bien jurídico específico, que no se encuentra directamente protegido por el Código penal.

\subsection{Empleo de medios fraudulentos para alterar el precio natural. Los acuerdos de precios entre oferentes no son medios fraudulentos en el sentido del Art. 285 del Código penal.}

De conformidad con el bien jurídico protegido en el Art. 285 del Código penal, esto es, la libre concurrencia entre oferentes y demandantes, el fraude típico es aquél que afecta a una parte significativa de unos y otros, de manera que en su concurrencia, mediada por el engaño de que son víctimas, acuerden un precio diferente del que habrían acordado sin mediar el engaño, tal como sucede ejemplarmente en el agio: una noticia falsa hábilmente publicada en el periódico acerca de la existencia o no de determinadas reservas o stock de una mercancía determinada o sobre la buena o mala posición económica de una empresa puede hacer subir o bajar el precio de dicha mercancía o de las acciones de aquella empresa, para beneficio de quienes conocen la realidad y perjuicio de quienes, desconociendo la realidad, adoptan acuerdos de precios diferentes a los que habrían llegado de no mediar el engaño o fraude.

Y ya se ha demostrado cómo la Comisión Redactora del Código penal entendió que las "coligaciones" o acuerdos entre oferentes de trabajo y de mercaderías (incluyendo las de primera necesidad) no podían considerarse ilícitas según el texto aprobado de los Arts. 285 y 286 del Código penal, pues no constituían otra cosa que "el ejercicio de un derecho" (la libertad de contratación).

Sin embargo, según Hernández, aunque se admitiese la licitud general de los acuerdos de precios entre oferentes, esta licitud no sería extensible a lo que denomina "colusiones secretas", esto es, acuerdos de precios desconocidos por los demandantes. Para llegar a esta conclusión señala que así lo permitiría concluir el bien jurídico que se protege en esta

\footnotetext{
${ }^{35}$ BAÑADOS, Florencio, Código penal de la República de Chile concordado y comentado, Santiago: L. A. Lagunas, 1920, p. 238. Recuérdese que el art. 419 Código penal francés sí sancionaba expresamente "la reunión o coligación entre los principales tenedores de una mercancía o artículo formada para no venderla, ó venderla a un determinado precio".

${ }^{36}$ HERNÁNDEZ, “La punibilidad de la colusión”, cit. nota n 1, p. 154.
} 
MATUS, Jean Pierre "De nuevo sobre la falta de punibilidad de los atentados contra la libre competencia, de conformidad con el Art. 285 del Código penal. Algunos aspectos de la discusión con Héctor Hernández en Política Criminal"

figura, el cual identifica con la libre competencia; una interpretación "sistemática" en relación con el artículo 287 del Código penal, donde se asimilarían amenazas y engaños; y un concepto amplio de engaño, que incluya los engaños concluyentes. ${ }^{37}$

En cuanto al primer y determinante argumento de Hernández, hay que repetir aquí que el bien jurídico protegido en el Art. 285 del Código penal es la libre concurrencia de oferentes y demandantes en un mercado determinado, y no la libre competencia, conceptos diferenciados y cuyas consecuencias para la compresión del texto también son diferentes: rechazar o no los acuerdos de precios y otras conductas monopolísticas como parte de la tipicidad de dicho Art. 285. La Comisión Redactora y la mejor doctrina chilena y española, de acuerdo con la evolución histórica de nuestra legislación y la del mundo entero, entendieron que el Art. 285 protegía la libre concurrencia y no la libre competencia, bien jurídico que se protegió especialmente en las regulaciones especiales del siglo XX. Por eso se sostuvo explícitamente al redactarse nuestro Código penal que las coligaciones de oferentes de trabajo y mercaderías de primera necesidad no constituían delito, sino el ejercicio lícito de un derecho.

Con relación a la interpretación sistemática basada en el texto del Art. 287 del Código penal, hay que decir dos cosas: ${ }^{38}$ primero, que éste no se refiere al agio o los atentados contra la libre concurrencia en un mercado determinado, sino específicamente a subastas públicas, donde el número de participantes está delimitado por su propia naturaleza y, en vez de varios oferentes concurrentes, sólo existe uno: la autoridad o particular que subasta. Y, en segundo lugar, que allí no se dice que las amenazas sean una forma de engaño, sino que se valoran del mismo modo, pues producen el mismo resultado: alejar postores de la subasta. ${ }^{39}$

Finalmente, en cuanto a la idea de que los medios fraudulentos incluyan también engaños concluyentes, ya en la primera edición de nuestras Lecciones de Derecho penal habíamos afirmado que la idea del engaño y el fraude en el Derecho chileno parece más amplia que la idea restrictiva de la misce en scène. ${ }^{40}$ Sin embargo, de allí no se deduce que los acuerdos

\footnotetext{
${ }^{37}$ HERNÁNDEZ, "La punibilidad de la colusión", cit. nota nº 1, p. 154 y s.

${ }^{38}$ Nótese aquí, con todo, que el argumento se rechaza por considerarse equivocado atendido el contenido del Art. 287 del Código penal y no porque rechacemos la argumentación sistemática en sí, como propone Hernández para no considerar la verdadera legislación antimonopolios al momento de dilucidar el sentido y objeto de protección del Art. 285 del Código penal.

39 Por estas mismas razones se debe rechazar la asimilación general que hace Hernández entre la legislación chilena, el fraude en las licitaciones de la regulación alemana (de nuevo, se trata de casos de oferente único y demandantes determinados, no de un mercado con libre concurrencia de unos y otros) y los acuerdos de precios atentatorios contra la libre competencia. En este aspecto, además, se debe agregar que las citas que se hacen a la legislación alemana relativa a los fraudes en las licitaciones omiten el hecho de que, en Alemania, los verdaderos atentados contra la libre competencia, esto es, la formación de carteles mediante acuerdos de precios, cuotas de mercados y otras conductas monopólicas, no se consideran punibles, sino infracciones administrativas, sujetas al control de la Bundeskartellamt, según la Gesetz gegen Wettbewerbsbeschränkungen de 27 de julio de 1957, cuyo $§ 1$ prohíbe "los acuerdos entre empresas, las decisiones de asociaciones de empresas y las prácticas concertadas que tengan por objeto o efecto impedir, restringir o distorsionar la competencia”, castigándolos únicamente con sanciones pecuniarias no penales.

${ }^{40}$ POLITOFF, Sergio; MATUS A., Jean Pierre; RAMÍREZ G., M ${ }^{\mathrm{a}}$ Cecilia, Lecciones de Derecho penal chileno, parte especial, Talca: Ed. U. de Talca, 2001, p. 159.
} 
Polít. crim. Vol. 8, № 15 (Julio 2013), Doc. 1, pp. 314 - 362.

[http://www.politicacriminal.cl/Vol_08/n_15/Vol8N15D1.pdf]

de precios u otras conductas monopolísticas puedan considerarse medios fraudulentos para alterar el precio natural de los objetos de contratación en el sentido del Art. 285 del Código penal.

En efecto, como ya hemos señalado, siguiendo a Cramer/Schönke/Schröder, es posible definir el engaño como "cualquier conducta que, influyendo en la representación intelectual de otro, le conduzca a una falsa idea de la realidad o lo mantenga en ella".,41

Luego, desde el punto de vista exclusivo del consumidor, que es el que parece adoptar Hernández cuando afirma que "el público reacciona cuando se entera de prácticas colusorias concretas", 42 la cuestión es determinar en qué medida un acuerdo de precios "secreto" afecta su libre concurrencia en el mercado.

Y la respuesta no puede sino ser negativa: ya sabemos que, según los miembros de la Comisión Redactora, esa libertad no se verá afectada por las coligaciones entre oferentes, en la medida que exista libertad de industria, esto es, la posibilidad legal o falta de trabas estatales para que otros oferentes ofrezcan precios diferentes, esto es, precios que los demandantes estén dispuestos a pagar.

Y ello sería así por cuanto en relación con el precio al que las cosas que se ofrecen a un consumidor o un grupo de consumidores determinados, un engaño se refiere en primer término al hecho de inducirles a la adquisición de las cosas ofrecidas a un precio diferente al que se le señaló en la oferta de venta, como si se le dijese que un bien cuesta una cantidad determinada según una fórmula que se le señala y, en definitiva, se le cobrase otra diferente bajo cualquier pretexto falso. En tales casos, el comprador habría recibido una información que le conduciría a tener una falsa o errónea representación de la realidad sobre el verdadero precio que el oferente había fijado a la cosa.

Pero en los casos en que los precios no están fijados por la autoridad, se publican de antemano, se pueden consultar por diferentes vías y se puede rechazar la oferta al conocerse su cantidad exacta, como sucede típicamente en las ventas minoristas de la actualidad, el comprador siempre tiene una representación de la realidad que se ajusta a la verdad: el precio de venta ofrecido es el precio de venta que se va a cobrar al momento del pago.

Luego, puede que el consumidor esté a gusto o disgusto con el precio ofrecido o hubiese tenido la expectativa de que éste fuese diferente, pero lo cierto es que a su respecto no habrá engaño alguno.

No influye en esta conclusión el hecho de que el o los compradores tuviesen determinada de antemano la compra, por las razones que sean, o que éstos esperasen un precio de oferta menor al efectivamente ofrecido. En ambos casos, se trata de situaciones en que, cualquiera sea la conducta del oferente, ésta no influye en la decisión del demandante y, por tanto, no existe engaño perjudicial o medio fraudulento alguno, por faltar la relación causal entre la

\footnotetext{
${ }^{41}$ POLITOFF/MATUS/RAMÍREZ, Lecciones de Derecho penal chileno, parte especial, cit. nota $\mathrm{n}^{\circ} 40, \mathrm{p}$. 423 y ss., donde se encuentran las correspondientes referencias bibliográficas.

${ }^{42}$ HERNÁNDEZ, "La punibilidad de la colusión”, cit. nota ${ }^{\circ}$ 1, p. 156.
} 
MATUS, Jean Pierre "De nuevo sobre la falta de punibilidad de los atentados contra la libre competencia, de conformidad con el Art. 285 del Código penal. Algunos aspectos de la discusión con Héctor Hernández en Política Criminal"

conducta del oferente y la disposición patrimonial (la decisión de compra del demandante). En el primero, porque se trata de una decisión preexistente, y en el segundo, porque se le informa previa y adecuadamente que el verdadero precio de la oferta no es el que él espera, sino otro diferente y, por lo tanto, no hay engaño alguno en cobrarle el precio informado previamente.

Nótese que, respecto del consumidor o comprador, la situación es idéntica tanto en casos de acuerdos de precios que él estime mayores a los que espera, como en la situación inversa, esto es, cuando los acuerdos de precios producen el efecto de dumping o precios depredatorios: el consumidor conoce el precio de venta y, aunque le resulte curioso que sea menor al que él esperaba o a los anteriores preexistentes, acepta la oferta libremente, pues adquiere el producto al precio ofertado y es ése precio el que se cobra efectivamente sin coacción ni engaño.

De lo anterior se deduce que ninguna influencia tiene para el precio que se informa al consumidor que éste haya sido acordado de manera "abierta" o "secreta" (distinción por lo demás inexistente en las leyes que castigan los acuerdos de precios). En efecto, tanto si el acuerdo es "abierto" o "secreto", ello no afecta al hecho de que el consumidor conoce de antemano el precio de lo que adquiere y no se emplea ninguna fórmula que, al momento del pago, lo altere. Y ello tanto si el precio aparece como excesivo (lo cual no obliga a comprar existiendo otros proveedores no "coludidos"), como cuando aparece como "beneficioso" para el consumidor, por provenir de una práctica depredatoria. Estos acuerdos no afectan la inteligencia del consumidor al momento de adquirir los bienes que se tratan, la libre concurrencia en el mercado, sino la libre competencia, que, como hemos repetido, es otro bien jurídico supraindividual (lo que queda muy claro cuando se trata de acuerdos de precios o prácticas "depredatorias" en que, durante el tiempo de su ejecución, los consumidores aparecen como "beneficiados" con precios bajos).

Como hemos señalado, la Comisión Redactora estaba consciente y así lo declaró expresamente, de que en casos de acuerdos entre oferentes, el mejor correctivo para precios inmoderadamente altos o que los demandantes no estuviesen dispuestos a aceptar sería la "libertad de industria" y no la aplicación del delito del Art. 285 del Código penal: las cosas no se venderían al precio ofrecido y terminarían entrando terceros a ofrecerlas al precio que los demandantes estuviesen dispuestos a pagar. Y ello, sin hacer distinción alguna acerca de si el acuerdo era "secreto" o "abierto", pues como resulta más o menos de Perogrullo, tales acuerdos y conductas monopolísticas se fundamentan en el secreto (y baste para confirmar este aserto las facultades legales que se confieren a la Fiscalía Nacional Económica, a fin de investigar y descubrir tales conductas).

\subsection{El precio natural de los objetos de contratación a la luz del bien jurídico protegido por el Art. 285 del Código penal.}

Según lo antes expuesto, en la historia del establecimiento del Art. 285 y la modificación sufrida por el actual Art. 286, fue determinante la intervención precisa en ella de Gandarillas, quien desempeñó el cargo de Ministro de Hacienda entre 1870 y 1871. Según este especialista, existiendo libertad de industria, los precios fijados por acuerdos entre 
Polít. crim. Vol. 8, № 15 (Julio 2013), Doc. 1, pp. 314 - 362.

[http://www.politicacriminal.cl/Vol_08/n_15/Vol8N15D1.pdf]

oferentes no podrían por sí solos alterar el precio natural de los objetos de contratación, ya que la inexistencia de trabas legales que impidieran el acceso de nuevos oferentes al mercado no gobernados por dichos acuerdos, serviría de correctivo suficiente de tales acuerdos. $^{43}$

Si bien se mira, desde el punto de vista económico, esta idea parece coincidir con la de un precio natural de largo plazo o equilibrio, que se acercaría bastante al concepto de precio natural en la obra de Adam Smith, considerado uno de los padres de la Economía Clásica inglesa del siglo XVIII. Según Smith, precio natural es "lo que realmente le cuesta [la mercancía] a la persona que la trae al mercado", lo que constituye una idea de precio natural como función del costo (en la obra de Smith, fuertemente asociado al trabajo). En cambio, precio de mercado, que "puede estar por encima, o por debajo, o coincidir exactamente con su precio natural", no sería otro que "el precio al que efectivamente cualquier mercancía es comúnmente vendida" en un mercado libre, precio que se encontraría regulado por "la proporción" entre las cantidades efectivamente demandadas y ofertadas en ese momento. ${ }^{44} \mathrm{Si}$ esto es así, ese precio de mercado es el que se obtiene de la libre concurrencia en un momento determinado, esto es, el precio de corto plazo, $\mathrm{y}$, en cambio el precio natural correspondería al precio de equilibrio o de largo plazo, ${ }^{45}$ pues en la medida que los costos de producción sean mayores que los precios durante un tiempo significativo, los productores dejarán de ofrecer dichos bienes al mercado para evitar la acumulación de pérdidas.

Sin embargo, con ser lo anteriormente dicho plausible, de acuerdo a la especialización técnica de Gandarillas, la identificación de precio natural de nuestro Art. 285 del Código penal con la misma expresión empleada por A. Smith tendría como consecuencia que éste no podría ser afectado por un fraude que, como el agio, ejemplo paradigmático de medio fraudulento en esta figura, no afecta el precio de largo plazo, sino únicamente la libre concurrencia en un momento determinado, esto es, la libre voluntad de quienes concurren al mercado en un momento dado, lo que, en el esquema de A. Smith, correspondería más bien al precio de mercado o de corto plazo.

Asumiendo esta dificultad para conciliar los conceptos de Smith con el texto del Código, y atendiendo el ambiente intelectual de la época, parece más acertado suponer que por precio natural se referían nuestros Comisionados al precio formado por la libre concurrencia entre oferentes y demandantes, tal como sostenía la Escuela Fisiocrática Francesa, entre cuyos autores Turgot afirmaba una estricta concepción subjetiva de la formación de precios. $^{46}$

\footnotetext{
${ }^{43}$ Sobre el significado de libertad de industria en este contexto, véase la nota $\mathrm{n}^{\mathrm{o}} 22$.

${ }^{44}$ SMITH, Adam, An Inquiry into the Nature and Causes of the Wealth of Nations, 1776, e-Book producido por C. Muir y D. Widger, pp. 162 y ss. Como señala precio natural en la obra de Smith puede verse desde la teoría moderna como precio de equilibrio o de largo plazo, que puede diferir actualmente del precio de mercado o de corto plazo, el cual no podría mantenerse por un lapso muy prolongado sobre o bajo el precio natural si se quiere seguir vendiendo o comprando esa mercancía en el largo plazo.

${ }^{45}$ SCHUMPETER, Joseph A., Historia del análisis económico, publicada sobre la base del manuscrito por E.B. SCHUMPETER, trad. M. SACRISTÁN, Barcelona: Ariel, 2012, p. 358.

${ }^{46}$ Es obvio que, por una cuestión simplemente temporal, no es posible buscar coincidencias acerca de qué sea un precio entre las concepciones de los legisladores españoles y chilenos de mediados del siglo XIX con las
} 
MATUS, Jean Pierre "De nuevo sobre la falta de punibilidad de los atentados contra la libre competencia, de conformidad con el Art. 285 del Código penal. Algunos aspectos de la discusión con Héctor Hernández en Política Criminal"

En efecto, en esta teoría, el precio de una mercadería correspondería a la media del conjunto de los precios acordados libre e individualmente por los contratantes, según sus propias valoraciones subjetivas de las cosas intercambiadas y sin atención a factores externos a dichas valoraciones:

"La necesidad recíproca ha llevado al intercambio de lo que la gente tiene por lo que no tiene. La gente cambia un tipo de producto por otro, o un producto por trabajo. En estos intercambios es necesario que las dos partes se pongan de acuerdo en la calidad y cantidad de cada una de las cosas que serán intercambiadas. En este acuerdo es natural que cada uno quiera recibir lo más que pueda y entregar lo menos que pueda; y siendo ambos igualmente entendidos de lo que tienen que entregar en el intercambio, cada uno tendrá que ponderar la valuación de la mercancía que entrega contra el deseo que tiene de la mercancía que desea recibir, y fijar de acuerdo con esto la cantidad de cada una a ser intercambiada. Si las partes no están de acuerdo será necesario que se acerquen cediendo un poco de cada parte, ofreciendo más o conformándose con menos. Supondré que uno tiene necesidad de maíz y el otro de vino, y que están de acuerdo en intercambiar un bushel de maíz por seis pintas de vino. Es evidente que cada uno de ellos mira a un bushel de maíz y a seis pintas de vino como exactamente equivalentes, y que en este intercambio en particular el precio de un bushel de maíz es seis pintas de vino, y el precio de seis pintas de vino es un bushel de maíz. Pero en otro intercambio entre otros hombres este precio será diferente, según uno de ellos tenga mayor o menor necesidad de la mercancía que posee el otro; y un bushel de maíz puede tal vez ser intercambiado por ocho pintas de vino, mientras que otro bushel será intercambiado por cuatro pintas. Ahora es evidente que ninguno de estos tres precios puede ser considerado como el verdadero precio de un bushel de maíz en relación con los otros; ya que con cada una de las partes contratantes el vino que ha recibido era el equivalente del maíz que había entregado: en resumen, mientras que consideremos cada intercambio aislado y autosuficiente, el valor de cada una de las cosas intercambiadas no tiene otra medida que la necesidad o deseo y los medios de las partes contratantes, compensadas unas con otras, y no se fija por ninguna otra cosa que el acuerdo de voluntades." 47

Luego, en esta teoría, no hay, en realidad, otro precio que el fijado por los contratantes libremente, y este precio es verdadero en todos los casos que el contrato se celebre libremente.

Sólo desde este punto de vista puede explicarse que la intervención de Gandarillas convenciera al resto de los miembros de la Comisión Redactora del Código penal, al punto de suprimir del Código toda mención a la "coligación" como medio para alterar el precio natural del trabajo o las mercaderías.

de las teorías actualmente vigentes, como la marginalista, la cual, aunque comenzó a discutirse en la década de 1850, sólo fue propuesta sistemáticamente por Alfred Marshall recién en 1890 (NICHOLSON, Walter, Teoría Microeconómica. Principios y Aplicaciones, 9a ed., México: CENAGE, 2009, p. 8),

47 TURGOT, Anne R. J., Reflections on The Formation and The Distribution of Riches (1766), Augustus M. Kelley, 1971, pp. 28-29, cit. por CACHANOSKY, Juan C, "Historia de las teorías del valor y del precio". Revista Libertas N 20 (1994), disponible en http://www.eseade.edu.ar/files/Libertas/25_4_Cachanosky.pdf 
Polít. crim. Vol. 8, № 15 (Julio 2013), Doc. 1, pp. 314 - 362.

[http://www.politicacriminal.cl/Vol_08/n_15/Vol8N15D1.pdf]

En efecto, si el precio natural es el que resulta del acuerdo libre entre oferentes y demandantes, la simple coligación de oferentes para vender a un precio determinado, no afecta ese precio natural, en tanto se mantenga la libertad de los demandantes para aceptar o rechazar dichos precios.

Este es el concepto que, por lo demás, contemplaba el modelo español de 1850 en su Art. 462, al definir los precios naturales como "aquellos que resultarían de la libre concurrencia", definición que no fue recogida en el texto aprobado por nuestra Comisión Redactora.

No existe ningún antecedente objetivo que explique el por qué nuestros legisladores no transcribieron esa definición en el Art. 285 del Código penal de $1874{ }^{48}$ Sin embargo, atendido lo antes expuesto en relación al bien jurídico protegido por esta disposición y las posibilidades de aplicación del texto legal, no parece problemático dar por buena la definición española para la comprensión de la expresión precio natural en el Código chileno.

Esta conclusión se ve reforzada por el hecho de que existe consenso en que durante el siglo XIX las ideas de libertad de empresa y de libertad contractual tendían a asociarse primordialmente con la de un Estado ausente en materia económica y sobre todo, no intervencionista. En palabras de Jorge López Santa María:

"Según los juristas del siglo pasado [XIX], lo contractual es necesariamente justo. Este decir es un axioma para el pensamiento económico liberal. El contrato garantiza la justicia y la utilidad social, pues el libre juego de las iniciativas individuales asegura espontáneamente la prosperidad y el equilibrio económico. La ley de la oferta y la demanda, en un mercado sin trabas ni proteccionismos, es la mejor garantía del bienestar [...] La economía únicamente precisa y tolera al Estado policía, cuyas funciones se circunscriben a ser el guardián de la paz". 49

\footnotetext{
${ }^{48}$ Aunque sí podemos especular acerca de la necesidad del legislador español para plantear esta definición, a fin de evitar la confusión con la ideal del precio natural dominante en la escolástica salamantina, desarrollada en el siglo XVI por Vitoria, Azpilcueta, Mercado, Alcalá y Molina. En efecto, los doctores de la Escuela de Salamanca asociaban el precio natural a un precio justo determinable objetivamente y que supuestamente tendrían los bienes y debería fijarse por el gobierno, ya sea como una función de su "costo" o "naturaleza" o como la resultante de una "estimación común" o del "hombre prudente".

Sobre la disputa acerca de si los escolásticos pueden considerarse precursores del libre mercado o no, véase el texto introductorio de Francisco GÓMEZ CAMACHO, Francisco a la edición del La Teoría del Justo Precio de Luis de MOLINA, (ed. Maxtor, 2011, pp. 23-108, especialmente, pp. 35-40), donde documentadamente da cuenta de que no es posible, como hacen algunos hoy en día, hacer coincidente la idea escolástica del justo precio con una teoría subjetiva del valor de cambio, pues a pesar del reconocimiento que éstos (y principalmente, Molina) hicieron de la utilidad, la escasez y el número de demandantes en la fijación del precio natural de las mercancías, su propósito era procurar ofrecer, criterios para la determinación del justo precio en una sociedad medieval fuertemente estratificada y donde la autoridad solía fijar los precios o procurar jueces para su fijación, y en ningún caso defender la libertad de comercio y emprendimiento, paradigma que sólo apareció en la vida social con la Escuela Clásica inglesa y la Fisiocráctica francesa.

49 LÓPEZ SANTA MARÍA, Jorge, Los Contratos. Parte General, $5^{\mathrm{a}}$ ed., actualizada por F. Elorriaga, Santiago: Legal Publishing, 2010, con referencias bibliográficas. Naturalmente, como demuestra el autor, los supuestos de esta forma de entender el liberalismo se mostraron falsos y ello ha llevado a la actualmente “ostensible declinación del dogma de la autonomía de la voluntad". Pero ello no empece a la conclusión de que este y no otro era el entendimiento de las relaciones económicas en el Chile del siglo XIX.
} 
MATUS, Jean Pierre "De nuevo sobre la falta de punibilidad de los atentados contra la libre competencia, de conformidad con el Art. 285 del Código penal. Algunos aspectos de la discusión con Héctor Hernández en Política Criminal"

Hernández, en cambio, a pesar de dar cuenta del concepto de precio natural del Art. 462 del Código español de 1850, como aquél que "resultaría de la libre concurrencia", ignora las diferencias conceptuales entre libre concurrencia y libre competencia, para afirmar a reglón seguido y sin ninguna otra justificación que sus propios dichos que el "precio natural es el que resulta de la libre competencia, del libre juego de la oferta y la demanda", añadiendo que, en realidad, según una moderna concepción económica, la alteración de dichos precios se produciría "cada vez que el precio no se haya obtenido bajo condiciones efectivas de competencia relativa". 50

Como se puede apreciar, con estas afirmaciones Hernández sencillamente confunde y sustituye el concepto de libre concurrencia por el de libre competencia, extendiendo así indebidamente el alcance de una figura penal que tiene sus orígenes en las ideas predominantes en el Chile del siglo XIX y no en el actual.

Naturalmente, después de las crisis del capitalismo industrial desde fines del siglo XIX se hizo patente en todo el mundo que la libertad de industria no era, por sí sola, suficiente para corregir las distorsiones que las conductas monopólicas producían en los mercados. De allí que, como también antes hemos señalado, paulatinamente fueron creándose legislaciones específicamente destinadas a sancionar esa clase de conductas, fenómeno que en Chile se manifestó con la aprobación de la Ley N 13.305 , de 1959 y hoy se regula en el Decreto Ley N² 211, de 1974, su sucesor legal.

Pero que ahora sepamos lo que sabemos acerca de las conductas atentatorias contra la libre competencia, no es razón para atribuir a las palabras del legislador de 1874 un sentido acorde con este conocimiento pero diferente al que expresamente se le pretendió dar por la Comisión Redactora, al excluir explícitamente los acuerdos o coligaciones entre oferentes de la sanción penal.

1.3.1. Relación entre la noción de justo precio del Art. 1888 del Código civil de 1856 y el precio natural del Art. 285 del Código penal de 1874.

A pesar de la evidente diferencia semántica, se ha planteado la cuestión de la relación entre ambos conceptos.

Al respecto, lo primero que debe decirse es que la regulación de la lesión enorme en los Arts. 1888 y siguientes del Código civil de 1856, que no se aplica a toda fijación de precios sino exclusivamente a las derivadas de compraventas que recaen sobre inmuebles, puede verse más que como antecedente del concepto de precio natural del Art. 285 del Código penal, como una suerte de resabio histórico, producto de la supervivencia de la teoría escolástica y su idea del precio justo, a partir del cual pueda decirse, objetivamente, que un bien inmueble ha sido vendido o comprado a menos o más del $50 \%$ de su justo precio, respectivamente. Para comprobar este aserto, basta transcribir en este lugar el Sumario de un texto de Luis de Molina, del año 1597, miembro de la Escuela escolástica de

${ }^{50}$ HERNÁNDEZ, “La punibilidad de la colusión”, cit. nota n 1, p. 163 y s. 
Polít. crim. Vol. 8, № 15 (Julio 2013), Doc. 1, pp. 314 - 362.

[http://www.politicacriminal.cl/Vol_08/n_15/Vol8N15D1.pdf]

Salamanca, en que se resume la Disputa acerca de la justicia de comprar bajo o sobre la mitad del justo precio de un bien:

"1. Peca la persona que compra a un precio inferior a la mitad del justo o vende o a un precio superior al justo en la mitad del mismo; y tanto en el fuero interno de la conciencia como en el externo, está obligada a restituir.

2. Si el justo precio de un bien fuera sólo 10 y se comprase por 4 ó 4,5, esa compra se habría efectuado por debajo de la mitad del justo precio, que es 5.

3. En la apreciación del justo precio debe considerarse el momento en que se celebra el contrato.

4. Supongamos que se hubiera vendido un bien por debajo de la mitad del justo precio y que, a su vez, el comprador lo hubiera vendido o entregado a otra persona, el vendedor podría actuar contra el comprador de forma que si no restituye el bien, por lo menos aumente la cantidad pagada inicialmente hasta alcanzar el margen del justo precio." ${ }^{, 51}$

Por otra parte, que la idea del justo precio objetivo deriva en una lesión que tenga como consecuencia la rescisión de los contratos es incompatible en cierto sentido con un sistema basado en la libertad de contratación, lo deja en claro el principal monografista nacional, don Arturo Alessandri R. Este autor, en su exhaustivo texto sobre La compraventa y el contrato de compraventa, propone la abolición de la lesión como acción para rescindir los contratos argumentando que "la lei no tiene por qué proteger a un contratante conciente $\mathrm{i}$ capaz de comprender lo que hace con perjuicio evidente de los intereses del otro". 52 Con independencia de la discusión acerca de si la ley puede o no proteger al contratante más débil, lo importante aquí es destacar cómo, desde el punto de vista de la doctrina que defiende la libertad contractual, la lesión aparece como una institución de difícil aceptación. Es más, el propio Alessandri, al definir el justo precio como el "valor en cambio" de las cosas, olvida su origen escolástico y adapta a la legislación civil a la ideología liberal de la codificación, pero pasa por encima de la tradición escolástica de este concepto, que supone, precisamente, un precio objetivo, independiente de las voluntades individuales que, de un modo u otro, se reflejan en las leyes de la oferta y la demanda. ${ }^{53}$

Finalmente, el hecho de que expresamente el Código civil excluya de la noción de lesión las diferencias de precios en las compraventas de bienes muebles nos indica las dificultades para hacer operativo un concepto objetivo de justo precio en relación con esta clase de bienes, que son a los que específicamente se refiere el Art. 285 del Código penal, aunque sin excluir a los bienes inmuebles, que pueden ser también, efectivamente, objeto de contratación.

\footnotetext{
${ }^{51}$ MOLINA, Luis de, La teoría del justo precio, Ed. Preparada por Francisco Gómez Camacho, ed. Maxtor, 2011, p. 177.

52 ALESSANDRI RODRÍGUEZ, Arturo, La Compraventa y la Promesa de Compraventa, Memoria de Prueba U. Chile, T. II, p. 1049.

53 ALESSANDRI, La Compraventa, cit. nota ${ }^{\circ}$ 52, p. 1059, identifica justo precio como "el valor intrínseco de la cosa", y éste como su "valor en cambio", entendido como "el que tiene la cosa en el comercio, el que se le asigna en las transacciones i cuya fijación se regula por la lei de la oferta y la demanda". A pesar de este esfuerzo de adaptación, parece difícil soslayar la tensión existente entre la idea de la formación de los precios por la libre concurrencia de oferentes y demandantes con la de un precio objetivo, que "pertenece a la cosa como algo inherente a ella" y que se reflejaría por su valor "en el comercio".
} 
MATUS, Jean Pierre "De nuevo sobre la falta de punibilidad de los atentados contra la libre competencia, de conformidad con el Art. 285 del Código penal. Algunos aspectos de la discusión con Héctor Hernández en Política Criminal"

\subsection{Excurso: El art. 285 del Código penal frente a la Ley $\mathbf{N}^{\circ} 18.045$, sobre Mercado de Valores.}

La Ley $\mathrm{N}^{\mathrm{o}} 18.045$ sobre Mercados de Valores, contempla las siguientes disposiciones:

"TITULO VIII

De las actividades prohibidas

Artículo 52.- Es contrario a la presente ley efectuar transacciones en valores con el objeto de estabilizar, fijar o hacer variar artificialmente los precios.

Sin perjuicio de lo dispuesto en el inciso anterior, podrán efectuarse actividades de estabilización de precios en valores de acuerdo a reglas de carácter general que imparta la Superintendencia y únicamente para llevar adelante una oferta pública de valores nuevos o de valores anteriormente emitidos y que no habían sido objeto de oferta pública.

Artículo 53.- Es contrario a la presente ley efectuar cotizaciones o transacciones ficticias respecto de cualquier valor, ya sea que las transacciones se lleven a cabo en el mercado de valores o a través de negociaciones privadas.

Ninguna persona podrá efectuar transacciones o inducir o intentar inducir a la compra o venta de valores, regidos o no por esta ley, por medio de cualquier acto, práctica, mecanismo o artificio engañoso o fraudulento.

\section{$[\ldots]$}

TITULO XI

De las sanciones

Art. 59. Sufrirán las penas de presidio menor en su grado medio a presidio mayor en su grado mínimo:

[...]

e) Las personas que infrinjan las prohibiciones consignadas en los artículos 52, 53, inciso primero del artículo 85 y letras a), d), e) y h) del artículo 162 de esta ley.”

Como señala Etcheberry, se trataría de

“disposiciones más minuciosas que las del Código, pero que se refieren a la misma finalidad: alterar artificialmente el precio resultante de las libres transacciones del mercado de valores" ${ }^{, 5}$

Es decir, se trataría de operaciones con acciones y otros valores que inducirían a un error en el resto de los demandantes y oferentes de los mismos, esto es, afectarían la libre concurrencia en el mercado de valores, con el resultado prohibido del Art. 52 de "estabilizar, fijar o hacer varias artificialmente los precios"; o mediante el artificio, maquinación o fraude indicado específicamente en su Art. 53, consistente en "efectuar cotizaciones o transacciones ficticias", caso en el cual la punibilidad se ampliaría a la tentativa de inducción.

\footnotetext{
${ }^{54}$ ETCHEBERRY, Derecho penal, parte especial, t. IV, cit. nota $\mathrm{n}^{\circ} 33$, p. 281.
} 
Polít. crim. Vol. 8, № 15 (Julio 2013), Doc. 1, pp. 314 - 362.

[http://www.politicacriminal.cl/Vol_08/n_15/Vol8N15D1.pdf]

Según Hernández, el hecho de que el Profesor Etcheberry haya dado cuenta de la existencia de esta regulación específica en la Ley de Mercado de Valores, en "el mismo contexto" de su tratamiento del agio del Art. 285 del Código penal, considerándola un caso de lex specialis de éste, sería un argumento más para considerar que en esta última disposición "la ley emplea la noción de 'medios fraudulentos' en términos amplios que exceden largamente del concepto de engaño" y que, en su concepto, abarcarían atentados contra la libre competencia, como los acuerdos de precios. ${ }^{55}$

Sin embargo, este argumento se ha de rechazar, primero, porque se parte de la conclusión a que se quiere llegar, esto es, que el Art. 285 del Código penal al igual que la Ley de Mercado de Valores protegerían la libre competencia, en circunstancias que Etcheberry expresamente señala otro bien jurídico para estos casos: "las libres transacciones" o libertad de concurrencia en el Mercado de Valores.

En segundo término, Hernández señala que Etcheberry consideraría la Ley de Mercado de Valores un caso de lex specialis frente al Art. 285 del Código penal, cosa que este autor no hace en ninguna parte. Lo que dice Etcheberry es que la regulación de la Ley de Mercado de Valores es "más minuciosa", no que se trata de una ley especial. Y ello es así, porque sólo

"existiría especialidad cuando todos los casos concretos que se subsumen en el supuesto de hecho legal de una norma, la especial, se subsumen también dentro del de otra norma, la general, la que es aplicable al menos a un caso concreto adicional no subsumible dentro del supuesto de hecho de la primera" 56

Luego, al contemplar la Ley de Mercado de Valores supuestos de hecho no contemplados en el Art. 285 del Código penal, como la punibilidad de la tentativa de inducción (Art. 53), caso expresamente puesto de relieve por Etcheberry (supuesto al cual se puede agregar el de la alteración de precios mediante coacción, que podría incluirse en al prohibición no especificada del Art. 52) no se puede afirmar que ella sea lex specialis frente al Art. 285 del Código penal, y por eso Etcheberry afirma que es una regulación "más minuciosa" y no dice que sea una lex specialis, como entiende Hernández. En realidad, estamos ante una regulación preferente, que es específica en cuanto al objeto sobre que recae (acciones y otros valores), pero mucho más amplia en cuanto a los medios de comisión y los sujetos responsables, que desplaza al Art. 285 en los supuestos en que coincide, pero abarca varios otros más, lo mismo que éste, en la medida que sanciona los atentados contra la libre concurrencia que alteran el precio natural del trabajo y otros objetos de contratación no comprendidos en el concepto de "acciones y otros valores" de la Ley No 18.045, situación que parece describirse mejor como subsidiariedad tácita antes que como simple especialidad. $^{57}$

\footnotetext{
${ }^{55}$ HERNÁNDEZ, "La punibilidad de la colusión", cit. nota n ${ }^{\circ} 1$, p. 153 y s.

${ }^{56}$ MATUS A. Jean Pierre, El Concurso Aparente de Leyes, Santiago: Ediciones Jurídicas de Santiago, 2008, p. 308.

${ }_{57}$ MATUS, El Concurso Aparente de Leyes, cit. nota ${ }^{\circ}$ 56, p. 313, donde se afirma que hay subisidiariedad tácita "cuando por lo menos un caso concreto que es subsumible en uno de dichos preceptos [concurrentes] lo es también en el otro, y por lo menos un caso concreto que es subsumible en el primero no lo es en el
} 
MATUS, Jean Pierre "De nuevo sobre la falta de punibilidad de los atentados contra la libre competencia, de conformidad con el Art. 285 del Código penal. Algunos aspectos de la discusión con Héctor Hernández en Política Criminal"

2. Sobre la inaplicabilidad por inconstitucionalidad del Art. 285 del Código penal a las conductas previstas y sancionadas administrativamente en el Decreto Ley $\mathbf{N}^{0} \mathbf{2 1 1}$, reformado por la Ley $\mathrm{N}^{\circ} \mathbf{1 9 . 9 1 1}$, de 14 de noviembre de 2003, en el evento que se admita la posibilidad de que éste abarcase también atentados contra la libre competencia.

Admitido que el Art. 285 del Código penal no protege atentados contra la libre competencia sino únicamente aquellos que, como el agio, afectan la libre concurrencia de oferentes y demandantes en un mercado determinado, carecería de sentido un estudio acerca de la posibilidad inconstitucionalidad de su aplicación en la actualidad, a la luz de las reglas relativas al principio de legalidad. Se trataría, en efecto, de una cuestión de mera delimitación típica de una norma vigente, carente de ribetes constitucionales.

Sin embargo, supuesto que los argumentos esgrimidos en la primera parte de este texto no fuesen suficientes para convencer acerca del sentido y alcance que se propone para el Art. 285 del Código penal y se diese por buena la propuesta de Hernández en el sentido de entender que dicha norma protegería también la libre competencia del modo que hoy en día la entendemos, surge la cuestión constitucional acerca de si la existencia de un cuerpo legal que regula completa y específicamente la materia desde el año 1959 (Título V de la Ley $\mathrm{N}^{\circ}$ 13.305, de 6 de abril), y cuyas disposiciones penales han sido expresamente derogadas, no conllevaría también la derogación del Art. 285 del Código penal respecto de aquellos supuestos hoy expresa y específicamente derogados tras las modificaciones al Decreto Ley $\mathrm{N}^{\mathrm{o}} 211$ de 1974, operadas por la Ley $\mathrm{N}^{\mathrm{o}} 19.911$, de 14 de noviembre de 2003, y por lo tanto, si la aplicación actual del Art. 285 del Código penal a atentados contra la libre competencia supone o no la aplicación de una ley derogada con infracción al principio de legalidad consagrado en el Art. 19 No 3 , inc. $8^{\circ}$ de la Constitución Política de la República.

La respuesta a esta pregunta es positiva, es decir, en mi opinión fundada en la historia de la legislación antimonopólica y sus posibilidades de interpretación y relaciones concursales con el resto del ordenamiento, hoy en día los ilícitos contra la libre competencia están sometidos exclusivamente al sistema especial administrativo de conocimiento y sanción establecido en el texto vigente del Decreto Ley $\mathrm{N}^{\circ} 211$, tras la despenalización de las conductas monopolísticas operada por la ley $\mathrm{N}^{\mathrm{o}} 19.911$ de 14 de noviembre de 2003, y por lo tanto, la aplicación de una disposición penal anterior y derogada respecto de esos hechos específicos, es inconstitucional, por resultar contraria al principio de legalidad establecido en el Art. 19 N $^{\circ} 3$ inc. $8^{\circ}$ de la Constitución Política de la República.

Para fundamentar esta conclusión, dividiré esta parte del texto en cuatro partes: en la primera, analizaré el sentido y alcance de la garantía constitucional infringida, y en especial en relación con el requisito de la vigencia de la ley a aplicar; en el segundo expondré las reglas aplicables acerca de la existencia o vigencia de una ley, su promulgación y derogación; en el tercero, expondré cómo el Título V de la Ley $\mathrm{N}^{\mathrm{0}}$ 13.305, de 6 de abril de 1959 derogó de manera tácita y orgánica toda legislación anterior e incompatible con sus

segundo, y viceversa, siempre que ambos preceptos compartan al menos una propiedad jurídico penalmente relevante en común". 
Polít. crim. Vol. 8, № 15 (Julio 2013), Doc. 1, pp. 314 - 362.

[http://www.politicacriminal.cl/Vol_08/n_15/Vol8N15D1.pdf]

sistema especial de persecución, incluyendo parcialmente el Art. 285 del Código penal de 1874, de admitirse aquella interpretación del mismo que considera también regulaba atentados contra la libre competencia. Luego, se explica la evolución de la legislación antimonopolio, que el legislador expresa e indubitablemente ha despenalizado en la actualidad, antecedente que impide cualquier intento de hacer "resurgir" o "volver a la vida" disposiciones penales derogadas en la materia, como pretende Hernández respecto del Art. 285 del Código penal. De este modo, se concluye que dicho precepto, encontrándose derogado, es inaplicable por inconstitucionalidad a las conductas monopólicas previstas y sancionadas administrativamente en el Decreto Ley $\mathrm{N}^{\circ} 211$, de conformidad con su derogación tácita y parcial operada por el Título V de la Ley $\mathrm{N}^{\circ} 13.035$, de 6 de abril de 1959, y la posterior despenalización de dichas conductas operada por el Ley $\mathrm{N}^{\mathrm{o}} 19.911$, de 14 de noviembre de 2003.

\subsection{El principio de legalidad y la exigencia de que exista una ley en sentido estricto que establezca el hecho punible y su sanción. Su resguardo mediante el recurso de inaplicabilidad.}

\subsubsection{Generalidades. Principio de legalidad y leyes derogadas.}

El principio de legalidad o de reserva legal de los delitos y de las penas se encuentra consagrado en los incs. $8^{\circ}$ y $9^{\circ}$ del art. 19 № 3 de la Constitución Política de la República, con arreglo a los cuales "ningún delito se castigará con otra pena que la que le señala una ley promulgada con anterioridad a su perpetración, a menos que una nueva ley favorezca al afectado" (nullum crimen nulla poena sine lege praevia) y "ninguna ley podrá establecer penas sin que la conducta que sanciona esté expresamente descrita en ella" (nullum crimen nulla poena sine lege scripta et certa). Ambos preceptos se encuentran también en el artículo $1^{\mathrm{o}}$ inciso primero del Código penal y el principio relativo a la legalidad de las penas se reitera asimismo en el artículo 18 del mismo cuerpo legal. Se consagra también el principio de reserva en la Declaración Universal de los Derechos Humanos (art. 11. 2), en el art. 15.1 del Pacto Internacional sobre Derechos Civiles y Políticos y en el art. 9 de la Convención Americana sobre Derechos Humanos. ${ }^{58}$

Por tanto, la única fuente inmediata y directa del derecho penal es la ley propiamente tal, esto es, aquella que, habiéndose dictado conforme a las exigencias materiales y formales de la Constitución, se encuentra vigente.

O, como sostenía Eduardo Novoa respecto del anterior texto constitucional: "de aquí resulta que una pena solamente puede ser aplicada si existe una ley previa que tenga el hecho por delictuoso y establezca para él esa pena". 59 De este modo, según Mario Garrido, "el

\footnotetext{
${ }_{58}^{58}$ POLITOFF/MATUS/RAMÍREZ, Lecciones de Derecho penal chileno, cit. nota n ${ }^{\circ}$ 40, p. 93.

${ }^{59}$ NOVOA, Eduardo, Curso de Derecho penal chileno, (1960), $3^{\text {a }}$ ed. anotada, Santiago: Ed. Jurídica de Chile, 2005, p. 111. El texto del Art. 11 de la Constitución Política del Estado de 1925 disponía: "Nadie puede ser condenado, si no es juzgado legalmente y en virtud de u a ley promulgada antes del hecho sobre que recae el juicio". El autor reconoce que el texto no se refiere tan claramente a la exigencia de legalidad de delitos y penas, aunque no duda de que "el texto legal y la voluntad del constituyente se refieren a ambos".
} 
MATUS, Jean Pierre "De nuevo sobre la falta de punibilidad de los atentados contra la libre competencia, de conformidad con el Art. 285 del Código penal. Algunos aspectos de la discusión con Héctor Hernández en Política Criminal"

principio general es que todo delito debe juzgarse con la ley que estaba vigente al tiempo de su ejecución", 60

Luego, al ser la ley la que determina las penas y los hechos punibles, del ámbito de los hechos ilícitos sólo algunos están "recortados" en la forma de figuras delictivas (tipos penales), que componen así un catálogo o "archipiélago"61 de hechos punibles. Esto es lo que le da al derecho penal un carácter fragmentario.

De allí que dicho principio permite, en ocasiones, que "un hecho especialmente refinado y socialmente dañoso, claramente merecedor de pena, quede sin castigo, pero éste es el precio (no demasiado alto) que el legislador debe pagar para que los ciudadanos estén a cubierto de la arbitrariedad y dispongan de la seguridad jurídica (esto es, que sea previsible la intervención de la fuerza penal del Estado)". ${ }^{62}$

En eso consiste la función de garantía que el Tribunal Constitucional le atribuye a este principio de legalidad, al permitir "el conocimiento anticipado de las personas del comportamiento que funda la responsabilidad penal". 63

Luego, parece posible sostener que la aplicación de una ley derogada, en la medida que no existe como fuente del Derecho vigente, infringiría directamente la garantía constitucional según la cual sólo pueden imponerse penas si la ley que las establece existe o se encuentra vigente.

Sin embargo, si se revisa la primera jurisprudencia del Tribunal Constitucional, podría llegarse a la conclusión inicial de que no le corresponde a éste declarar la inaplicabilidad de una norma derogada cuya aplicación a un caso concreto produzca eventualmente efectos contrarios a la Constitución, pues esta Magistratura sostenía que la "derogación expresa o tácita es un tema de diferente naturaleza, consistente en la determinación de la vigencia y eficacia temporal de las normas, que será determinada por los jueces del fondo y que es revisable por vía de apelación y casación" (STC 29.01.2012, Rol N 991-07, considerando $7^{\circ}$ ), y "por ende, no corresponde a esta Magistratura, tal como lo ha declarado en otras oportunidades, adentrarse en cuestiones sobre vigencia por sucesión de leyes en el tiempo (roles $\mathrm{N}^{\mathrm{o}} \mathrm{s}$ 503-06, considerando noveno; 513-06, considerando séptimo; 796-07, considerando vigesimoséptimo, y 976-07, considerando decimosexto)" (STC 24.08.2010, Rol No $1532-2009$, considerando $7^{\circ}$ ).

\footnotetext{
${ }^{60}$ GARRIDO MONTT, Mario, Derecho Penal, Parte General, T. I, reimp. 1ª ed., Santiago: Ed. Jurídica, 2003, p. 105. El subrayado es del autor.

${ }^{61}$ BELING, Ernesto, Esquema de Derecho Penal, SOLER, Sebastián (Trad.), Buenos Aires, 1944, p. 37.

${ }^{62}$ ROXIN, Claus, Strafrecht. Allgemeiner Teil. Band I Grundlagen der Aufbau der Vebrechenslehre. $3^{a}$ edición, Munich, 1997, § 5/3, p. 96.

${ }^{63}$ STC 14.06.2012, Rol No 2154-11-INA. Donde se aclara, en todo caso, citando la STC Rol No 549-2007, que "el carácter expreso - claro, patente, especificado- que, conforme a la Constitución, debe contener la descripción de la conducta, no se identifica con totalidad o integridad, sino que está asociado a la comprensión y conocimiento por las personas de sus elementos esenciales".
} 
Polít. crim. Vol. 8, № 15 (Julio 2013), Doc. 1, pp. 314 - 362.

[http://www.politicacriminal.cl/Vol_08/n_15/Vol8N15D1.pdf]

No obstante, como demuestra el ex Ministro de ese Tribunal, don Enrique Navarro B., esta primera doctrina se ha ido matizando y modificando pues no es posible sostenerla en todos los casos sin que de ello se derive el peligro de aplicar una ley derogada, produciendo con ello un efecto contrario a la Constitución. ${ }^{64}$

En efecto, si se revisan los casos a que las primeras declaraciones del Tribunal Constitucional hacen referencia podrá observarse que en ellos la cuestión de la derogación planteada no dice relación directa con la infracción o no de la garantía constitucional de que nadie puede ser sancionado sino por un hecho que sea delito de conformidad con una ley vigente al momento de su comisión, sino con cuestiones de diversa naturaleza, como las reglas vigentes para determinar el precio de los planes de salud (Rol 976-07), las facultades de la Contraloría General de la República respecto a los Alcaldes (Rol 796-07), la vigencia del Decreto Ley $N^{\circ}$ 2695, sobre regularización de la pequeña propiedad raíz (Rol 991-07), las causales para rechazar un recurso de reclamación de derechos de aguas (Rol 503-06) y su tramitación (Rol 513-06).

Sólo en el caso de la STC de 29.01.2012, Rol N 991-07, la infracción constitucional que se reclamaba era relativa a una concreción del principio de legalidad, a saber, al principio de retroactividad favorable, alegando los recurrentes que no debía serles aplicable el Art. 509 del Código de Procedimiento Penal de 1906, sino el Art. 351 del Código Procesal de 2000, pues la regla relativa a la reiteración de delitos de este último es más favorable que la del primero.

Sin embargo, la mayoría de los Ministros que concurren al fallo, lo hacen pronunciándose sobre la inexistencia de la derogación alegada, por la falta de aplicación del Art. 351 del Código Procesal Penal de 2000 respecto de hechos acaecidos con anterioridad a su promulgación, como eran los del caso de autos.

Así, los Ministros Bertelsen y Fernández Baeza concurren al fallo pero hacen ver que la norma que eventualmente sería contraria a la Constitución no sería el Art. 509 del Código de Procedimiento Penal de 1906, sino el Art. 483 del Código Procesal Penal de 2000, que limita su ámbito de aplicación temporal a los hechos acaecidos con "posterioridad a su entrada en vigencia”, dando a entender que sin impugnar ese artículo no puede aplicarse el 351 de dicho cuerpo legal. Por su parte, la Ministra Peña y los Ministros Fernández Fredes, Carmona y Viera Gallo añaden que

“el precepto legal invocado como más favorable en la acción no es aplicable al caso sub lite, por estar expresamente excluido por otra norma de rango constitucional. En efecto, el principio de aplicación de la ley posterior más favorable al inculpado exige lógicamente que esa pretendida ley posterior sea susceptible de aplicación, lo que en el caso de autos no permite el inciso segundo de la disposición octava transitoria de la propia Constitución, que limita la vigencia de las normas del Código Procesal Penal sólo a hechos delictuales cometidos con posterioridad a la vigencia de ese orden de enjuiciamiento."

\footnotetext{
${ }^{64}$ NAVARRO B., Enrique, El control de constitucionalidad de las leyes en Chile (1811-2011), Santiago: Cuadernos del Tribunal Constitucional, $\mathrm{N}^{\circ} 43,2011$, p. 78 y s.
} 
MATUS, Jean Pierre "De nuevo sobre la falta de punibilidad de los atentados contra la libre competencia, de conformidad con el Art. 285 del Código penal. Algunos aspectos de la discusión con Héctor Hernández en Política Criminal"

De donde se puede concluir que en un caso donde la existencia de un verdadero conflicto de leyes en el tiempo sí produjese un efecto contrario a la Constitución, como sería si de éste se derivase la posibilidad de aplicar una ley penal no vigente, derogada o una más desfavorable que la autorizada por la Constitución, entonces sí sería necesaria la declaración de inconstitucionalidad, para evitar su infracción.

Así se ha resuelto en la STC 27-09-2007 (Rol No 781-07), donde, estudiando la inaplicabilidad del Art. 299 No 3 del Código de Justicia Militar, delito de incumplimiento de deberes militares, en relación a un caso concreto donde las normas complementarias no existían y, por lo mismo, no podían estar vigentes al momento de los hechos (aunque sí se publicaron con posterioridad), se declaró la inaplicabilidad de dicho texto legal al caso, pues su aplicación ocasionaría efectos contrarios a la garantía del principio de legalidad del inciso final del art. $19 \mathrm{~N}^{\circ} 3$.

Es más, apreciando los efectos de la declaración de inconstitucionalidad de una norma legal, el propio Tribunal Constitucional ha matizado su jurisprudencia contraria al análisis de la vigencia de las normas en juego, aceptando declarar inaplicable una disposición que previamente se había derogado y expulsado del sistema al declararse inconstitucional por dicha Magistratura (STC 28.10.2010, Rol N 1552-2009).

Y lo mismo ha dicho posteriormente respecto de una norma derogada por el legislador (STC 04.11.2010, Rol No 1399-2009), sosteniendo:

"Noveno: Que, en opinión de estos sentenciadores, resulta perfectamente posible pronunciar un veredicto de inaplicabilidad por inconstitucionalidad respecto de un precepto legal que, a la fecha de la sentencia respectiva, se encuentre derogado por el legislador, siempre y cuando, como sucede en la especie, dicha norma hubiere estado en vigor en el momento en que se suscitó la situación jurídica regida por ella y deba ser aplicada por el juez de la gestión pendiente al momento de resolver el asunto;

Décimo: Que, en efecto, lo que la Constitución ha exigido en esta materia es que el precepto impugnado resulte aplicable al caso de que se trate, toda vez que en su artículo 93, $\mathrm{N}^{\circ} 6^{\circ}$, prescribe que es atribución del Tribunal Constitucional el declarar la inaplicabilidad de un precepto legal "cuya aplicación en cualquier gestión que se siga ante un tribunal ordinario o especial, resulte contraria a la Constitución", no exigiendo que el mismo se encuentre actualmente vigente. Con ello, el constituyente previó acertadamente la hipótesis de la ultra actividad de una disposición derogada, es decir, de aquellas normas que si bien no rigen respecto de situaciones fácticas que acontezcan en la actualidad, sí regían en el momento en que ocurrieron los hechos que se juzgan. Así, por lo demás, lo ha estimado esta propia Magistratura en sentencia Rol $\mathrm{N}^{\circ} 728-2007$ "

Por lo tanto, como a falta de derogación expresa y retiro de las ediciones de los textos normativos de un precepto legal, tácita y parcialmente derogado, éste puede llegar a ser aplicado en un caso concreto, como sucedería si por cualquier causa - por ejemplo, admitiendo una querella a tramitación - se inicia una investigación criminal bajo ese título, produciendo con ello la posibilidad de su aplicación contraria a la Constitución, si se 
Polít. crim. Vol. 8, № 15 (Julio 2013), Doc. 1, pp. 314 - 362.

[http://www.politicacriminal.cl/Vol_08/n_15/Vol8N15D1.pdf]

aplica en aquellas materias en que ya no rige, correspondería también al Tribunal Constitucional la declaración de su inaplicabilidad, sin perjuicio de las facultades de los tribunales de fondo en caso de que el Tribunal Constitucional no llegue a conocer del asunto.

\subsection{Principio y término de la vigencia de una ley penal.}

Como bien enseña Labatut,

"en cuanto al tiempo de su vigencia, las leyes penales, como por lo demás todas las leyes, según lo prescriben los arts. $6^{\circ}, 7^{\circ}, 52$ y 53 del Código Civil, rigen desde el momento de su publicación hasta su derogación, sin perjuicio de lo que en ellas se establezca sobre la fecha de su entrada en vigor". ${ }^{65}$

A ello cabe agregar que, hoy en día, la Constitución regula estrictamente el proceso de formación de las leyes, previo a su entrada en vigencia, y también algunos casos especiales de derogación, producto de la declaración de inconstitucionalidad que de una ley puede hacer el Tribunal Constitucional.

A continuación analizaremos con detalle ambos fenómenos jurídicos.

\subsubsection{Inicio de la vigencia de una ley: promulgación y publicación.}

Para entrar en vigor, una ley debe cumplir con los requisitos que establece la Constitución, esto es, ser promulgada y publicada. Una ley ha de entenderse promulgada cuando así lo decrete el Presidente de la República, dentro de los diez días contados desde que ello sea procedente, en conformidad con lo dispuesto a los Arts. 72 a 75 de la Constitución Política, o cuando así lo declare en su fallo el Tribunal Constitucional, en virtud de la facultad otorgada en su Art. 93 Nº 5. En ambos casos, el trámite promulgatorio de una ley es distinto al de su publicación, tal como aparece en lo dispuesto en los Arts. 75 de la Constitución y $6^{\circ}$ y $7^{\circ}$ del Código Civil. En efecto, la promulgación de una ley queda afinada una vez que la Contraloría General de la República ha tomado razón del decreto promulgatorio (Art. 75 en relación con el Art. 93, ambos de la Constitución Política.). La publicación es un trámite posterior (Art. 75 Constitución Política y ${ }^{\circ} 7$ Código Civil), que sólo incide en la obligación de aplicar la ley promulgada cuando impone o agrava penas (Art. $6^{\circ}$ Código Civil), pero no cuando establece un régimen penal más favorable o exime al hecho de toda pena (Art. 18 del Código penal y $19 \mathrm{~N}^{\circ} 3$, incs. $8^{\circ}$ y $9^{\circ}$ Constitución Política de la República), supuesto en el cual basta su promulgación para hacerla aplicable. ${ }^{66}$

\footnotetext{
${ }^{65}$ LABATUT, Gustavo, Derecho Penal, T. I., $9^{a}$ ed., actualizada por J. ZENTENO, Santiago: Ed. Jurídica, Reimp. de 1995, p. 50.

${ }^{66}$ Véase al respecto, por la doctrina mayoritaria, ETCHEBERRY, Alfredo, Derecho Penal, T. I. $3^{a}$ ed., Santiago: Ed. Jurídica, 1998, pp. 144 y 148.
} 
MATUS, Jean Pierre "De nuevo sobre la falta de punibilidad de los atentados contra la libre competencia, de conformidad con el Art. 285 del Código penal. Algunos aspectos de la discusión con Héctor Hernández en Política Criminal"

\subsubsection{Término de su vigencia: derogación.}

De conformidad con la doctrina absolutamente dominante entre nosotros, la derogación es "la abolición de las normas jurídicas", y a través de ella "se priva a las normas de fuerza obligatoria". 67

El Código civil señala al respecto, en sus artículos 52 y 53, lo siguiente:

"Artículo 52. La derogación de las leyes puede ser expresa o tácita.

Es expresa, cuando la ley nueva dice expresamente que deroga la antigua.

Es tácita, cuando una nueva ley contiene disposiciones que no pueden conciliarse con las de la ley anterior.

La derogación de una ley puede ser total o parcial".

“Artículo 53. La derogación tácita deja vigente en las leyes anteriores, aunque versen sobre la misma materia, todo aquello que no pugna con las disposiciones de la nueva ley"

En España, la doctrina dominante también reconoce que, específicamente, "las leyes permanecen vigentes hasta que son derogadas por otras leyes.", 68 admitiéndose que "la derogación producida por la nueva ley puede ser expresa, cuando se menciona directamente la ley o norma que resulta derogada, o tácita, cuando simplemente se lleva a cabo una regulación incompatible con la ley o norma anterior". 69

Según la doctrina civil más autorizada, "es indudable la mayor conveniencia de usar la derogación expresa", pues con ella "se evita las dudas", facilitando la labor del juez, pero que existen "diversas razones" para no recurrir a ella: pereza legislativa, rapidez del proceso de despacho de las leyes, imposibilidad de tener presente todas las leyes aplicables en la materia.

Por lo mismo, la derogación tácita opera siempre que se dicte una nueva ley, aunque ella nada diga al respecto. Es más, según la doctrina citada, la existencia de la regla de la derogación tácita en el Código Civil "pone de manifiesto la inutilidad del artículo final de

\footnotetext{
${ }^{67}$ FIGUEROA Y., Gonzalo, Curso de Derecho Civil, T. I., 5 ${ }^{a}$ ed., Santiago: Ed. Jurídica de Chile, 2011 , p. 27.

${ }^{68}$ Ver, por todos, recientemente, MARAVER, Mario, "Vigencia temporal de la ley penal", en: LASCURAIN, Juan Antonio (Coord.), Introducción al Derecho penal, Madrid: Thomson Reuters, 2011, p. 171 y s.

${ }^{69}$ MARAVER, "Vigencia temporal de la ley penal", cit. nota $n^{\circ}$ 68, p. 171 y s. OLIVER, Guillermo, Retroactividad e irretroactividad de las leyes penales, Santiago: Ed. Jurídica de Chile, 2007, pp. 35 y ss., llega a las mismas conclusiones, aunque advierte que "no es fácil encontrar casos en que el legislador penal se haya valido de derogaciones tácitas stricto sensu" (dando en todo caso como ejemplo el nuevo Art. 212 del Código penal chileno respecto del 210), pero reconoce que muchas veces, cuando el legislador declara que "quedan abrogadas todas las leyes anteriores incompatibles con la nueva ley", estamos también ante casos de derogación tácita, que denomina "derogaciones tácitas <<expresadas $>>$ ". No obstante agrega que sus características "exigen mucha prudencia en su operatividad", sin llegar a hacer suya la aislada doctrina italiana y de teoría general (que no tienen la correspondencia de los textos positivos italianos y chilenos) que niega el carácter verdaderamente derogatorio de esta clase de derogación reconocida legalmente entre nosotros.
} 
Polít. crim. Vol. 8, № 15 (Julio 2013), Doc. 1, pp. 314 - 362.

[http://www.politicacriminal.cl/Vol_08/n_15/Vol8N15D1.pdf]

muchas leyes chilenas y francesas, cuyo tenor declara abolidas "todas las leyes contrarias a la presente"," 70

Siguiendo la doctrina civil, "la derogación es tácita cuando la nueva ley contiene disposiciones que no pueden conciliarse con las de la ley anterior", 71 esto, cuando son incompatibles, de modo que su aplicación conjunta conduciría a contradicciones insalvables, pues

"es indudable que si con posterioridad a una ley general se promulga una especial, ésta prevalece sobre aquélla en todo lo que sean incompatibles; deroga las disposiciones que no puedan coexistir con las suyas propias. Esto resulta de la mera aplicación de los principios generales de la derogación tácita". ${ }^{72}$

Además, según L. Ortega, existe "otra especie de derogación tácita: la derogación orgánica", que ocurre cuando el legislador, "sin una necesidad de regulación expresa", "regula toda la materia ya regulada por la ley anterior", no siendo "indispensable que exista incompatibilidad entre la antigua y la nueva ley", sino más bien, que la segunda ley "se hay inspirado en principios distintos de los que lo movieron a dictar la primera". ${ }^{73}$

\subsubsection{Efectos de la derogación.}

Cualquiera que sea la clase de derogación que se trate, sus efectos son los mismos: la expulsión del sistema de la ley o disposición derogada, sin posibilidad de volver a regir, salvo remisión expresa de una ley posterior que así lo permita:

"Es necesario, pues, que una ley expresamente devuelva su vigor a la ley derogada: la simple abolición de la ley derogatoria no puede por si sólo dar vida a lo que ya no existe. Y es lógico que así sea. La ley es la declaración positiva y actual del legislador; su existencia no puede desprenderse por meras conjeturas". ${ }^{74}$

Y si lo dicho vale para el Derecho civil, mucho más ha de ser necesario respecto del Derecho penal, donde la garantía del principio de legalidad impone considerar no punibles aquellos hechos que no están expresamente descritos como delitos en una ley vigente al momento de su comisión (artículo 19 No 3, inciso $8^{\circ}$ de la Constitución Política de la República). Luego, parafraseando la cita anterior, podríamos decir, que un delito derogado por una ley posterior no puede "revivirse" por efecto de meras conjeturas acerca del alcance

${ }^{70}$ ALESSANDRI R., Arturo; SOMARRIVA U., Manuel; VODANOVIC H., Antonio, Derecho Civil, T. I, Parte General y de las Personas, $2^{a}$ ed., Santiago: Ed. Nascimento,1945, p. 218. Una disposición de esa naturaleza, que seguía a la del artículo 181 de la Ley $N^{\circ} 13.305$ en el proyecto aprobado por la Cámara de Diputados en su primer trámite constitucional, fue suprimida por el Senado, entendemos por ser, precisamente, inútil (Informe Comisiones Unidas del Senado, Diario de Sesiones del Senado, Sesión 20ª (1959) (Anexo Documentos), pp. 755-855, especialmente pp. 705p., 766s, y 795. La disposición proyectada y suprimida decía: "Artículo 134. Se derogan todos aquellos preceptos legales y reglamentarios contrarios a las disposiciones de este Título".

${ }^{71}$ FIGUEROA, Derecho Civil I, cit. nota ${ }^{\circ} 67$, p. 27.

${ }^{72}$ ALESSANDRI/SOMARRIVA/VODANOVIC, Derecho Civil I, cit. nota $\mathrm{n}^{\circ}$ 70, p. 222.

${ }^{73}$ ORTEGA, Leopoldo, "De la derogación de las leyes y especialmente de la derogación orgánica", Revista de Derecho y Jurisprudencia T. XXXV (1938), Primera Parte, pp. 6-12, p. 8 y s.

${ }^{74}$ ALESSANDRI/SOMARRIVA/VODANOVIC, Derecho Civil I, cit. nota $\mathrm{n}^{\circ}$ 70, p. 222 
MATUS, Jean Pierre "De nuevo sobre la falta de punibilidad de los atentados contra la libre competencia, de conformidad con el Art. 285 del Código penal. Algunos aspectos de la discusión con Héctor Hernández en Política Criminal"

de la derogación de esa ley posterior, si tal "resurgimiento" no ha sido expresamente establecido por el legislador, como expresión de su voluntad soberana. ${ }^{75}$

\subsection{4. ¿Resurgimiento o vuelta a la vida de leyes penales derogadas?}

De conformidad con lo ya expuesto, no es posible aceptar como regla general que una ley derogada, expresa o tácitamente, resurja o vuelva a la vida con posterioridad a su derogación, sin que exista una expresa declaración legal en orden a establecer nuevamente su vigencia.

No obstante, Héctor Hernández sostiene que en materia penal este resurgimiento sí sería posible sin expresa declaración legal en los supuestos de derogación tácita, afirmando que entre leyes penales tal clase de derogación no operaría en caso alguno, sino que en materia penal siempre estaríamos única y exclusivamente ante supuestos de concurso aparente de leyes $^{76}$.

Sin embargo, dicha propuesta refleja una confusión conceptual, pues aunque puede concederse que en los conflictos de leyes penales que se regulan bajo la teoría del concurso aparente de leyes, se admite el resurgimiento de la ley desplazada en ciertas condiciones, esta afirmación supone un conflicto entre leyes simultáneamente vigentes, lo que no ocurre cuando una de ellas está derogada, expresa o tácitamente. O, dicho de otra forma: que la teoría del concurso aparente de leyes nada tiene que ver con la de la vigencia de éstas, que es su presupuesto.

En efecto, sólo se puede afirmar que no hay una verdadera derogación tácita en los casos de concurso aparente de leyes, cuando las normas concurrentes son compatibles o redundantes o, lo que es lo mismo, cuando se trata de normas cuya aplicación simultánea no produzca antinomias ni contradicciones insalvables. Pero ello no sucede cuando la vigencia de una es incompatible con la de otra, caso en que se produce derogación tácita de la ley anterior por la posterior y no concurso aparente de leyes.

Así, por ejemplo, no son incompatibles las leyes penales que se encuentran en una relación de especialidad sencilla, regidas por las mismas normas procesales y que pueden ser aplicadas simultáneamente. Por ejemplo, si bien el nuevo delito de femicidio de la ex conviviente prefiere al delito de homicidio, si en el futuro se derogasen expresamente tanto el parricidio como el femicidio, los hechos seguirían siendo punibles a título de homicidio, título que resurgiría o volvería a la vida para sancionar hechos a los que, actualmente, no es en principio aplicable. El nuevo delito de femicidio, por tanto, no habría derogado en lo que tiene de nuevo a la figura del homicidio, que seguiría vigente, pero no aplicable mientras también esté vigente la de femicidio. De hecho, tampoco lo habría "derogado" durante su vigencia, pues es conocida la posibilidad de castigar por la figura de homicidio a quien mate a su cónyuge desconociendo que lo es (Art. $1^{\circ}$, inc. $3^{\circ}$ del Código penal), o a

\footnotetext{
${ }^{75}$ MATUS A., Jean Pierre, La Ley Penal y su Interpretación, $2^{a}$ ed., Santiago: Ed. Metropolitana, 2012, p. 227.

${ }^{76}$ HERNÁNDEZ, “La punibilidad de la colusión”, cit. nota n 1, p. 158.
} 
Polít. crim. Vol. 8, № 15 (Julio 2013), Doc. 1, pp. 314 - 362.

[http://www.politicacriminal.cl/Vol_08/n_15/Vol8N15D1.pdf]

quien colabore con el femicidio que otro comete, sin tener noticias de la relación conyugal existente entre victimario y víctima (Art. 64 Código penal). Aquí estamos ante dos normas de vigencia simultánea y, además, compatibles, ninguna de las cuales ha derogado a la otra.

En cambio, son incompatibles y producen derogación tácita de la ley anterior, aquellas cuya aplicación simultánea no es posible. Ello ocurre entre nosotros, por ejemplo, cuando la nueva ley establece delitos con un sistema procesal independiente, entregando la facultad de iniciar la acción penal a organismos especiales o a la víctima; o cuando es indiscutible la voluntad del legislador y del texto legal en orden a despenalizar una conducta, entregando su persecución y sanción de ciertos hechos a un organismo administrativo.

Ello explica por qué, aún desde la perspectiva del concurso aparente de leyes, el resurgimiento de la ley en principio desplazada no se admite en todos los supuestos.

Así, la doctrina mayoritaria en Alemania y España en ningún caso lo acepta cuando con ello se pasa a llevar una regla que atribuye a personas determinadas la facultad de iniciar o no un proceso penal mediante querella o denuncia, pues con ello tal requisito quedaría anulado de facto; ni tampoco cuando se pasa a llevar un privilegio, como sería precisamente el caso de imponer pena o imponer una pena más grave a un hecho particular que el legislador especialmente ha tenido en cuenta para despenalizarlo o privilegiarlo, respectivamente. $^{77}$

2.3. La derogación tácita y orgánica de toda normativa penal anterior, incluyendo parcialmente el Art. 285 del Código penal, en la parte pertinente, respecto de los hechos atentatorios contra la libre competencia que debían ser conocidos y sancionados por el sistema especial administrativo establecido en la Ley $\mathbf{N}^{\circ} 13.035$ de 6 de abril de 1959, que establecía "normas para fomentar la libre competencia industrial y comercial".

Ya hemos expuesto en la primera parte de este trabajo nuestra interpretación acerca del sentido y alcance de este texto legal, en donde se concluye que en él no cabe ver una regulación de los atentados contra la libre competencia, como ahora los concebimos, excluyendo expresamente los delitos de coligación para fijar el precio de las cosas, sino una figura apta para sancionar exclusivamente los agios o cualesquiera otras maniobras fraudulentas (engañosas) que recaigan sobre terceros y provoquen una alteración del precio natural de las mercaderías.

Esta interpretación es coincidente con la general afirmación de que la protección y regulación de la libre concurrencia por parte del Estado, como se entendió entre nosotros tras la crisis del año 1929, no podía encontrarse en las reglas del Código penal de 1874, según el cual, en todos los casos, los precios de las mercaderías serían determinados por una real "libre concurrencia" de oferentes y demandantes en el mercado, salvo la existencia de coacción o fraude contra personas determinadas.

\footnotetext{
77 Ver con detalles y referencias bibliográficas: MATUS A., Jean Pierre, El Concurso aparente de leyes penales, Santiago: Ed. Jurídicas de Santiago, 2008, pp. 122-124 y 273-277. Véase también, del mismo: Revista de Derecho (U. Católica de Coquimbo), No 9 (2002), pp. 27-68.
} 
MATUS, Jean Pierre "De nuevo sobre la falta de punibilidad de los atentados contra la libre competencia, de conformidad con el Art. 285 del Código penal. Algunos aspectos de la discusión con Héctor Hernández en Política Criminal"

Sin embargo, Héctor Hernández propone que el Art. 285 del Código penal se interprete en el sentido de que también abarcaría supuestos de atentados contra la libre competencia, como los que él denomina "colusiones secretas" de precios.

Pero si así fuese, demostraremos a continuación que el Art. 285 del Código penal habría sido tácita y parcialmente derogado en todo lo que dice relación con la sanción de actos atentatorios contra la libre competencia y, en particular, respecto de los acuerdos de precios, cuotas de producción o de mercado, distribución exclusiva, etc., por las disposiciones contempladas en el Título V de la Ley No 13.035 de 6 de abril de 1959 y, por lo tanto, que su aplicación en la actualidad a supuestos tales como los acuerdos produciría un efecto contrario a la Constitución, por suponer la imposición de penas contempladas en leyes que no se encuentran vigentes para dichos casos.

En efecto, la Ley $\mathrm{N}^{\circ} 13.305$, de 6 de abril de 1959 se dictó 85 años después de la entrada en vigencia del Código de 1874, dentro de un proceso general de expansión de la regulación de la actividad económica como una de las respuestas a la crisis del capitalismo basado en el laissez faire del siglo XIX, ${ }^{78}$ y reguló por primera vez, de manera específica y consciente la existencia de supuestos en que la libertad de contratación se dificultaría, en especial, en situaciones que pueden calificarse como "monopólicas", de "posición dominante" o formación de "carteles" en el mercado, donde los grados de libertad de una de las partes concurrentes podrían (aunque no necesariamente) llegar a ser muy superiores a los de la otra, según las condiciones de cada mercado en particular, confiriéndole una posición que le conceda el control de los precios o de la producción de ese mercado en particular.

Es por ello que esta regulación puede verse como un derecho nuevo y singular. ${ }^{79}$ Derecho nuevo no sólo por su lejanía temporal con el Código penal 1874, sino por la materia a tratar: las actividades contra la libre competencia respecto de las cuales de presupone la incapacidad del libre consentimiento para validarlas. Y singular, pues no se conformó con establecer una tipificación especial de delitos respecto de los cuales se pudiesen aplicar directamente las normas penales y procesal penales comunes, sino también requisitos de procesabilidad extraordinarios, intervención de órganos administrativos creados ad-hoc para su persecución, y un procedimiento más o menos extraordinario.

En efecto, en cuanto tipificación especial, es claro que en nuestra legislación los acuerdos de precios y otras conductas monopolísticas no aparecieron específicamente sancionados sino hasta la entrada en vigencia de la mencionada Ley $\mathrm{N}^{\circ} 13.035$, cuyo Art. 173 sancionaba con la pena de presidio menor en cualquiera de sus grados y multa,

“Art. 173. Todo acto o convención que tienda a impedir la libre competencia dentro del país, sea mediante convenios de fijación de precios o repartos de cuotas de

\footnotetext{
${ }^{78}$ Sobre este proceso histórico y su influencia en el proceso legislativo, véase MATUS A., Jean Pierre, "Evolución Histórica del Derecho Penal Chileno", en: MATUS: Legislación penal vigente en Chile, Tomo I, Santiago, Thomson Reuters, 2012, pp. 3-175, p.p. 60-93.

${ }^{79}$ Las categorías están tomadas del texto de GUZMÁN BRITO, Alejandro, "Codificación, descodificación y recodificación del Derecho civil en Chile", Revista de Derecho y Jurisprudencia, TOMO XC (1993), N², pp. 39-62 [tomada de MICROJURIS: MJCH_MJD117 | RDJ 90-2-39].
} 
Polít. crim. Vol. 8, № 15 (Julio 2013), Doc. 1, pp. 314 - 362.

[http://www.politicacriminal.cl/Vol_08/n_15/Vol8N15D1.pdf]

producción, transporte o de distribución de zonas de mercado; sea mediante acuerdos, negociaciones o asociaciones para obtener reducciones o paralizaciones de producción; sea mediante la distribución exclusiva, hecha a una sola persona o sociedad, de varios productores del mismo artículo específico, o por medio de cualquier otro arbitrio que tenga por finalidad eliminar la libre competencia [...]"

Otra singularidad en la tipificación, consistió en el establecimiento de responsabilidad penal para las personas jurídicas, al respecto de las cuales disponía el inciso final del artículo 173:

"En el caso de personas jurídicas, si se tratare de reincidencia, además de la multa señalada en el inciso primero y de la responsabilidad penal que sea imputable a sus representantes, podrá el Tribunal aplicar, como pena accesoria la cancelación de la personalidad jurídica, la revocación de la autorización de existencia si se tratare de una sociedad anónima o de una agencia de sociedad anónima extranjera, o la disolución anticipada en los demás casos. La sentencia que aplique estas penas, tratándose de una sociedad anónima o comercial o de una agencia de sociedad anónima extranjera deberá ser inscrita en el Registro de Comercio respectivo y publicada en el "Diario Oficial"."

Al mismo tiempo, se estableció un órgano especial, "la Comisión", compuesta por un Ministro de la Corte Suprema y los Superintendentes de Bancos y Compañías de Seguros, Sociedades Anónimas y Bolsas de Comercio (artículo 175), encargado de "conocer, ya sea de oficio o a petición de cualquiera persona natural o jurídica, de las situaciones que puedan estar comprendidas en el artículo 173, a fin de declarar si procede o no la iniciación del proceso respectivo ante los Tribunales de Justicia” (artículo 175, letra a)).

A ello se añadió un requisito especial de procesabilidad: el inicio del proceso penal por medio de querella o denuncia por parte del Consejo de Defensa del Estado, "a requerimiento de la Comisión" (artículo 177), amén de algunas importantes modificaciones procesales, particularmente en lo relativo a la apreciación de la prueba (en conciencia), el Tribunal competente (un Ministro de Corte de Apelaciones), y las facultades de investigación conferidas a la Comisión y al Consejo de Defensa del Estado (artículos 178 a 180).

Este conjunto de singularidades hace a la regulación específica del delito monopolístico que allí se estableció incompatible, absolutamente, con la supuesta regulación general que se contendría en el Art. 285 del Código penal.

En efecto, según se señala en la historia de su establecimiento, mientras el Proyecto contenido en el Mensaje del Ejecutivo contemplaba como única limitación para el ejercicio de la acción penal por esta clase de infracciones una denuncia o querella previa del Consejo de Defensa del Estado (régimen ya diferenciado de la acción pública que contemplaba el artículo 285 del Código penal), al estudiarse el mismo en las Comisiones Unidas de la Cámara de Diputados, y con la finalidad dar al comercio y a la industria la seguridad de que este delito no sería empleado en su contra "en forma abusiva, mediante denuncias o querellas infundadas", se acordó establecer el sistema de "calificación previa" por parte de una Comisión permanente, formada por un Ministro de la Corte Suprema y los 
MATUS, Jean Pierre "De nuevo sobre la falta de punibilidad de los atentados contra la libre competencia, de conformidad con el Art. 285 del Código penal. Algunos aspectos de la discusión con Héctor Hernández en Política Criminal"

Superintendentes de Bancos y de Sociedades Anónimas. ${ }^{80}$ Luego, sólo cuando esta Comisión estableciera la efectividad de una infracción de las normas antimonopolios, se podían enviar los antecedentes a la justicia ordinaria a través del Consejo de Defensa del Estado, restando la posibilidad de que los jueces y los particulares pudieran accionar de oficio o por medio de querellas o denuncias sobre estos hechos. ${ }^{81}$ Este sistema quedó reflejado básicamente en los artículos 175 y 177 de la Ley $\mathrm{N}^{\circ} 13.305$. Es más, el artículo 179 del texto aprobado entregó la competencia para conocer de estos asuntos a un Ministro de la Corte de Apelaciones respectiva, privando de ella a los jueces ordinarios que sí tenían competencia para conocer de los casos por infracción al artículo 285 del Código penal.

De allí se desprende que la intención manifestada objetivamente en la ley y en la historia de su establecimiento era que las infracciones a la libre competencia se regirían por un sistema diferenciado tanto en su penalidad (que pasaba a regirse por el artículo 173 de la Ley $\mathrm{N}^{\circ}$ 13.305), como en la forma de ejercer la acción penal, dejando de ser pública propiamente tal, y en la competencia para su conocimiento, quedando entregado en primer lugar a una Comisión y, sólo en caso que ésta así lo decidiera, a un Ministro de Corte de Apelaciones.

Por lo tanto, de ser cierto que el artículo 285 del Código penal castigase ya en 1874 la celebración de acuerdos o convenciones para fijar precios, cuotas de producción, de mercado como casos especiales de alteración fraudulenta de los precios naturales de las cosas, no lo es menos que casi 85 años después, de manera explícita e indubitable, el artículo 173 de la Ley $\mathrm{N}^{\mathbf{0}}$ 13.305, una norma posterior, sí lo contempló como un caso especial de delito monopolístico, sometido a un régimen procesal nuevo y singular, incompatible con el Derecho penal común.

En efecto, de sostener lo contrario, habría que suponer que durante toda la vigencia de la Ley $\mathrm{N}^{\mathrm{o}} 13.305$ las conductas monopolísticas que no se hubiesen declarado atentatorias contra la libre competencia por la Comisión que dicho cuerpo legal establecía, sea por no haberse sometido a su conocimiento o por haber ésta rechazado el requerimiento, podrían haberse perseguido penalmente por el régimen ordinario que correspondía al Código penal de 1874, lo que habría frustrado el propósito y objetivos del sistema especialmente diseñado para su investigación y sanción por la Ley $\mathrm{N}^{\circ} 13.305$, esto es, evitar su persecución por la justicia ordinaria a través de denuncias y querellas de particulares, estableciendo un antejuicio ante la Comisión, reservando el ejercicio de la acción penal exclusivamente al Consejo de Defensa del Estado.

Luego, por tratarse el artículo 173 de la Ley $\mathrm{N}^{\circ} 13.305$ de una ley especial y posterior, incompatible con el artículo 285 del Código penal, debe entenderse que éste fue derogado parcial y tácitamente la regulación penal común de los delitos monopolísticos, si es que fuera cierto que ella se pudiera reconducir a una interpretación extensiva del texto del Art. 285 del Código penal.

\footnotetext{
${ }^{80}$ Este sistema, al que luego se le agregó la Fiscalía Nacional Económica pervivió en su estructura básica en el Decreto Ley $\mathrm{N}^{\mathrm{o}} 211$, mientras las conductas monopólicas se consideraban infracciones penales, esto es, hasta la entrada en vigencia de la Ley $\mathrm{N}^{\circ}$ 19.911, de 2003, que despenalizó estos hechos, sometiéndolos exclusivamente a la jurisdicción del Tribunal de la Libre Competencia.

${ }^{81}$ Diario de Sesiones de la Cámara de Diputados, Sesión 29a , lunes 26 de enero de 1959, p. 1667.
} 
Polít. crim. Vol. 8, № 15 (Julio 2013), Doc. 1, pp. 314 - 362.

[http://www.politicacriminal.cl/Vol_08/n_15/Vol8N15D1.pdf]

Además, si se mira el conjunto de la regulación del Título V de la Ley $\mathrm{N}^{\mathrm{o}}$ 13.305, como un derecho nuevo y singular que regulaba toda la materia relativa a los atentados contra la libre competencia, podrá convenirse que esta Ley de 1959 vino a derogar orgánicamente todas las normas particulares y dispersas que pudieran referirse a los atentados contra la libre competencia, entre ellas, el supuestamente también aplicable artículo 285 del Código penal de 1874 en la parte en que, de conformidad con la hipótesis dialéctica con que trabajamos, sancionaría la conducta consistente en acordar precios, hecho prototípicamente atentatorio contra la libre competencia.

Esta derogación orgánica se ve refrendada, además, por la literalidad del artículo 181 de la Ley $\mathrm{N}^{\mathrm{o}} 13.305$, cuyo contenido fue ampliamente discutido por los legisladores, en orden a determinar qué normas relativas a los monopolios dejarían expresamente subsistentes tras su promulgación. De donde se desprende, a contrario sensu, que aquellas disposiciones cuya vigencia no fue refrendada explícitamente, debían entenderse derogadas, de conformidad con los principios generales recién analizados.

Pues bien, la sola lectura de este artículo 181 lleva a la conclusión que, en ningún caso, fue la voluntad del legislador ni de la propia ley, dejar subsistente la eventual sanción penal de los acuerdos de precios bajo la norma general del artículo 285 del Código penal de 1874, que no es mencionada entre las normas que expresamente se dejan vigentes.

El artículo en cuestión dispone:

“Artículo 181. No obstante los preceptos de este Título, continuarán vigentes en todas sus partes las disposiciones legales y reglamentarias referentes a la Minería, especialmente el petróleo, a la producción, comercio y distribución del salitre, yodo y cobre; las contenidas en el Código Sanitario; las referentes a alcoholes y las que regulan la creación y funcionamiento de las empresas de servicios públicos o municipales; las relativas a empresas bancarias, de seguros, de reaseguros y bolsas de valores, como también las que digan relación con los transportes, fletamentos y cabotaje, ventas al martillo y crédito prendario.

Igualmente quedarán en vigor todas las disposiciones legales y reglamentarias que confieren a las autoridades atribuciones relacionadas con el ejercicio de actividades económicas o industriales, incluso aquellas que se refieren a la fijación de precios máximos a los artículos de primera necesidad y control de su cumplimiento."

2.4. La situación actual: despenalización de las conductas monopólicas perseguidas y sancionadas por el sistema administrativo especial creado al efecto por la Ley $\mathbf{N}^{\circ} \mathbf{1 9 . 9 1 1}$, de 14 de noviembre de 2003.

2.4.1. Antecedentes previos: consolidación institucional del sistema de protección penal y administrativa de la libre competencia: el Decreto Ley $\mathrm{N}^{\mathrm{o}} 211$.

Como es sabido, el Decreto Ley No 211, de 22 de diciembre de 1973, teniendo presente "que las normas destinadas a fomentar la libre competencia industrial y comercial que prevé el título $\mathrm{V}$ de la ley $\mathrm{N}^{\mathrm{o}} 13.305$, modificado por la ley $\mathrm{N}^{\mathrm{o}} 15.142$ [que estableció por primera vez un funcionario semejante a la Fiscalía en la materia], si bien tienen mérito conceptual no contemplan una estructura orgánico-funcional que las haga operativas y 
MATUS, Jean Pierre "De nuevo sobre la falta de punibilidad de los atentados contra la libre competencia, de conformidad con el Art. 285 del Código penal. Algunos aspectos de la discusión con Héctor Hernández en Política Criminal"

eficaces en todo el país" ( $\mathrm{N}^{\mathrm{o}} 5^{\circ}$ ), derogó dicho cuerpo legal (artículo cuarto transitorio), consolidando un sistema de protección de la libre competencia administrativo y penal a la vez, mediante el establecimiento de un nuevo órgano encargado de la investigación preliminar de los hechos atentatorios contra la libre competencia, la Fiscalía; y nuevas Comisiones Preventivas Provinciales (posteriormente, Regionales) y Central; así como el reemplazo de la antigua "Comisión" por una "Comisión Resolutiva", ahora con facultades sancionadoras de carácter administrativo propias.

Sin embargo, en lo "conceptual", y con referencia exclusiva a la tipificación penal de los acuerdos de precios atentatorios a la libre competencia, la situación no se alteró demasiado, tal como lo anunciaban los considerandos del mencionado Decreto Ley $\mathrm{N}^{\mathrm{o}} 211$.

En efecto, ahora la tipificación del delito contra la libre competencia se depuraba del casuismo de su antecesora, reduciéndose a castigar con presidio menor en cualquiera de sus grados al "que ejecute o celebre, individual o colectivamente, cualquier hecho, acto o convención, que tienda a impedir la libre competencia en la producción o en el comercio interno o externo" (artículo $1^{\circ}$ ), considerando su artículo $2^{\circ}$ como "actos o convenciones" de esa naturaleza, "los que se refieran al comercio o distribución, sea mayorista o al detalle, tales como el reparto de cuotas o la asignación de zonas de mercado o de distribución exclusiva, por una sola persona o entidad, de un mismo artículo de varios productores" (letra c)).

En cuanto al castigo penal de las personas jurídicas, se elimina la mención a la reincidencia y se establece una disposición especial para el caso de ser responsables del delito sociedades anónimas extranjeras (artículo $4^{\circ}$ ).

Como ya mencionamos, la principal novedad de este cuerpo legal consistió en el establecimiento de un importante sistema orgánico encargado de la prevención, investigación y persecución de los atentados a la libre competencia y su represión, compuesto por las mentadas Comisiones Preventivas Provinciales (posteriormente Regionales) y Central, la Fiscalía y la Comisión Resolutiva (artículo 6º, organismo este último que vino a reemplazar en sus funciones a la "Comisión" del artículo 175 de la Ley $\mathrm{N}^{\mathrm{o}}$ 13.305, y estaba compuesta por un similar grupo de autoridades, a las que se agregaban el Director Nacional de Industria y Comercio, el de Impuestos Internos y el Síndico General de Quiebras (artículo 16). Esta nueva Comisión Resolutiva pasa a tener facultades sancionadoras de carácter administrativo en el conocimiento, "a requerimiento del Fiscal", de "las situaciones que pudieren importar infracciones al presente decreto ley" (artículo 17). Entre estas facultades sancionadoras administrativas se cuentan las de poner término a los actos o contratos contrarios a la libre competencia, declarar ciertas inhabilidades, ordenar la modificación o disolución de sociedades y aplicar multas. Junto a estas nuevas facultades, la Comisión Resolutiva conserva la de la anterior Comisión en cuanto a la facultad de poner en marcha el proceso penal, ahora expresada en la potestad de "ordenar al Fiscal el ejercicio de la acción penal respecto de los delitos a que se refieren los artículos $1^{\circ}$ y $2^{\text {or }}$ (artículo 17, $\mathrm{N}^{\mathrm{o}}$ 5). 
Polít. crim. Vol. 8, № 15 (Julio 2013), Doc. 1, pp. 314 - 362.

[http://www.politicacriminal.cl/Vol_08/n_15/Vol8N15D1.pdf]

Requerido el ejercicio de la acción penal por parte de la Comisión Resolutiva, se mantiene como requisito especial de procesabilidad la presentación de una querella o denuncia, ahora por el Fiscal, quien puede actuar por sí o por delegado en el proceso (artículos 31 y 32), bajo un procedimiento similar al ya establecido por la ley $\mathrm{N}^{\mathrm{o}} 13.305$ (apreciación de la prueba en conciencia; un Ministro de Corte de Apelaciones como Tribunal de instancia); pero con mayores facultades de investigación tanto para el Juez como para el Fiscal (artículos 33 a 37 y 23).

Finalmente, y al igual que ocurría con la Ley $\mathrm{N}^{\mathrm{0}}$ 13.035, para disipar toda duda de regulación, se estableció una regla derogatoria general, mediante la técnica de dejar subsistentes las disposiciones que expresamente indica, derogando así las no mencionadas y relativas a la misma materia. ${ }^{82}$

En resumen, sin alterar significativamente el sistema de persecución penal de los delitos contra la libre competencia el Decreto Ley $N^{\circ} 211$ al consolidar la institucionalidad protectora, le confirió a la Fiscalía y las Comisiones Preventivas y Resolutiva facultades para sancionar administrativamente las mismas conductas constitutivas del delito y ejercer, discrecionalmente, la acción penal a su respecto. Se dio comienzo así al proceso de administrativización de las conductas contrarias a la libre competencia, el que culminaría con la dictación de la Ley $\mathrm{N}^{\circ} 19.911$.

De esta realidad normativa, en que los acuerdos o convenciones contrarios a la libre competencia sólo se encontraban regulados en el Decreto Ley $\mathrm{N}^{\circ} 211$, con sanciones tanto administrativas como penales, previo requerimiento de la Comisión Resolutiva, da cabalmente cuenta el Oficio del Fiscal Nacional del Ministerio Público, dictado antes de la despenalización operada por la Ley $\mathrm{N}^{\mathrm{0}}$ 19.911, sobre "Investigación de los Delitos Contenidos en la Ley Antimonopolios", donde se señala que, "el hecho, acto o convención atentatorio contra la competencia no es una figura estrictamente penal, sino que constituye principalmente un ilícito administrativo", por lo que sólo la finalidad de impedir la libre competencia, sumada al hecho objetivo, podría dar lugar a un delito, aunque reconoce que ha sido escasamente perseguido, siendo privativa de la Comisión Resolutiva la decisión de requerir o no el ejercicio de la acción penal, transformándose así estos delitos en aquellos “de acción pública, previa instancia particular". Como era de esperarse, en ninguna parte de

\footnotetext{
82 "Artículo 5\%. Sin perjuicio de lo establecido en el presente decreto ley, continuarán vigentes las disposiciones legales y reglamentarias referidas a las propiedades intelectual e industrial, a la minería, especialmente al petróleo, a la producción, comercio y distribución del salitre, yodo y cobre; las contenidas en el Código Sanitario; las contempladas en la Ley de Alcoholes y Bebidas Alcohólicas; las que regulan la creación y funcionamiento de las empresas de servicios públicos o municipales; las relativas a empresas bancarias, de seguros, de reaseguros y bolsas de valores; como también las que digan relación con los transportes, fletamentos y cabotajes, ventas al martillo y crédito prendario.

Igualmente quedarán en vigor las disposiciones legales y reglamentarias que confieren a las autoridades atribuciones relacionadas con el ejercicio de las actividades económicas, incluso aquellas que se refieren a la fijación de precios máximos y control de su cumplimiento.

Con todo, no podrá establecerse ningún estanco, ni aún en virtud de los preceptos referidos en los dos incisos precedentes sin previo informe favorable de la Comisión Resolutiva.

La Comisión Resolutiva podrá requerir la modificación o derogación de los preceptos señalados en este artículo en cuanto, limitando o eliminando la libre competencia, los estime perjudiciales para el interés común."
} 
MATUS, Jean Pierre "De nuevo sobre la falta de punibilidad de los atentados contra la libre competencia, de conformidad con el Art. 285 del Código penal. Algunos aspectos de la discusión con Héctor Hernández en Política Criminal"

este Oficio se instruye de manera general el ejercicio de la acción penal en relación con los artículos 285 del Código punitivo, para los casos en que alguna de las instituciones del sistema del Decreto Ley $\mathrm{N}^{\mathrm{o}} 211$ no ejerciese sus facultades o, requerida la acción penal por ese cuerpo legal, fuese por cualquier motivo imposible seguir con ella. Al contrario, el Oficio reseñado reafirma que, respecto a estos hechos, la acción penal pública sólo podía ejercerse después de la investigación administrativa y sólo a requerimiento de la Comisión Resolutiva. $^{83}$

2.4.2. Despenalización de las conductas contrarias a la libre competencia: la Ley No 19.911 , de 14 de noviembre de 2003.

En un artículo aparecido el año 1997, el entonces Abogado Asesor de la Fiscalía Nacional Económica, Sr. Radoslav Depolo Razmilic, afirmaba que "no aparece apropiado, en una etapa de madurez del sistema económico chileno, utilizar normas penales para su protección", pues

\begin{abstract}
"la economía nacional es una de las más abiertas y competitivas del mundo; no existen barreras de peso a la entrada o salida de nuevos competidores, sean nacionales o extranjeros; y el empresario está consciente de que el Estado cumple una labor fiscalizadora respecto de aquellos actos que atenten o puedan atentar contra la libre competencia. A estas alturas -agregaba el asesor del Fiscal Nacional Económico-, los fines de protección que persigue el DL 211 pueden obtenerse por la sola aplicación de su faz administrativa sancionatoria, y no por el ejercicio de la acción penal". ${ }^{4}$
\end{abstract}

Recogiendo esta propuesta, el Mensaje Presidencial No 132-346 con el se inició el Proyecto de Ley que creó el Tribunal de Defensa de la Libre Competencia, de 17 de mayo de 2002, planteaba entre sus objetivos, aparte de las reformas orgánicas que ello suponía, la despenalización total y absoluta de las conductas contrarias a la libre competencia, tanto por razones de técnica legal (la dificultad de conciliar una regulación amplia con el principio de legalidad), como de eficacia (la aparente falta de fuerza disuasoria de las sanciones penales en la materia, en comparación con la que tendrían las fuertes multas que se proyectaban). Para evitar cualquier duda de interpretación al respecto, transcribiré a continuación la parte pertinente del Mensaje aludido:

\title{
“III. 3. Eliminación del carácter penal.
}

Todo tipo penal debe describir las conductas que sanciona de manera precisa, de forma que los sujetos a los cuales se dirige la norma tengan la certeza de aquello que está prohibido por el legislador.

\footnotetext{
${ }^{83}$ El oficio citado se encuentra impreso en el texto MINISTERIO PÚBLICO, FISCALÍA NACIONAL. Reforma procesal penal. Oficios del Fiscal Nacional en materias penales. 2001-2004. Santiago: Ed. Jurídica de Chile, 2005, 488 pp., pp. 225-249.

${ }^{84}$ DEPOLO RAZMILIC, Radoslav, "El régimen jurídico de defensa de la competencia en Chile. Algunas proposiciones para su despenalización”, Revista de Derecho de la Universidad Católica de Valparaíso, t. XVIII (1997), pp. 435-441, p. 439. Y añade, desde el punto de vista empírico, lo siguiente: en un universo de más de dos mil causas, "la acción penal contemplada en el DL 211 ha sido ejercida en dos ocasiones, en ninguna de las cuales llegó a prosperar”.
} 
Polít. crim. Vol. 8, № 15 (Julio 2013), Doc. 1, pp. 314 - 362.

[http://www.politicacriminal.cl/Vol_08/n_15/Vol8N15D1.pdf]

Sin embargo, el escenario actual en el que se desenvuelven los agentes económicos es complejo, por lo que es importante no introducir reglas que señalen per se las conductas que constituyen atentados en contra de la libre competencia. La experiencia mundial indica que hoy que cada caso debe ser estudiado en su propio mérito, de acuerdo con sus complejidades y particularidades. Por estos motivos, resulta aconsejable mantener una norma amplia con ejemplos básicos, para que los integrantes del organismo encargados de conocer las causas decidan, de acuerdo al caso concreto, qué conducta constituye un atentado a la libre competencia.

Sin embargo, este enfoque es incompatible con la existencia de una figura penal, en la cual la especificación del tipo es un requisito ineludible, so pena de vulnerar la garantía constitucional establecida en el inciso final del número 3 del artículo 19 de nuestra Constitución.

Como contrapartida a la eliminación del carácter penal, que rara vez ha dado paso a la acción penal y se estima que no ha logrado disuadir las conductas contra la libre competencia, se propone aumentar las multas y hacer responsables solidariamente de su pago a los directores, gerentes o administradores de las empresas que incurrieren en ellas."

De conformidad con lo anterior, habrá que entender que el colegislador consideró incompatible sancionar penalmente la conducta que describía en el proyectado nuevo Artículo $3^{\circ}$ letra a) del Decreto Ley $N^{\circ} 211$, consistente en celebrar o ejecutar "acuerdos expresos o tácitos entre agentes económicos, o las prácticas concertadas entre ellos, que tengan por objeto fijar precios de venta o de compra, limitar la producción o asignarse zonas o cuotas de mercado", prefiriendo entregar su prevención y sanción al Tribunal de la Libre Competencia y a la Fiscalía Nacional Económica, particularmente con las importantes sanciones pecuniarias establecidas en el que terminó por ser el actual artículo 26 del Decreto Ley $\mathrm{N}^{\circ} 211$, según el Texto refundido del mismo, promulgado por el Decreto con Fuerza de Ley $N^{\circ} 1$ de Economía, publicado en el Diario Oficial de 7 de marzo de 2005.

Desde luego, así lo entendió también el Centro de Estudios Libertad y Desarrollo, vinculado a los entonces partidos políticos de oposición. En un extenso informe sobre el contenido del Proyecto de Ley de marras, se señala, respecto de la eliminación del carácter penal de estas conductas, que "la eliminación es positiva", pues

"No es adecuado sancionar infracciones económicas con las propiamente penales, sino que con castigos de carácter también económico, que operan como forma de desincentivar las conductas. Además hay que considerar que muchas veces las situaciones son discutibles y poco claras, dado lo complejo de los escenarios comerciales." $\$ 5$

Durante la tramitación el Proyecto, tampoco se puso en duda la despenalización operada.

\footnotetext{
${ }^{85}$ DOMPER, M ${ }^{\mathrm{a}}$ de la Luz; BUCHHEISTER, Axel, Tribunal de la Competencia: Modificaciones a la institucionalidad antimonopolio en Chile. Serie Informe Económico $\mathrm{N}^{\circ} 133$. Santiago: Instituto Libertad y Desarrollo, 2002, 42 pp., p. 38.
} 
MATUS, Jean Pierre "De nuevo sobre la falta de punibilidad de los atentados contra la libre competencia, de conformidad con el Art. 285 del Código penal. Algunos aspectos de la discusión con Héctor Hernández en Política Criminal"

Así, en su Informe preceptivo, la Excma. Corte Suprema da cuenta de esta despenalización, pero no hace observación particular alguna. ${ }^{86}$ En la discusión habida en la Comisión de Economía de la H. Cámara de Senadores, al elaborarse el Primer Informe de la tramitación correspondiente, el entonces Ministro de Economía, insistió en la eliminación del carácter penal de estas conductas, citando "el mensaje que acompaña al proyecto, donde ya se dijo que el carácter penal es incompatible con una ley en la que difícilmente se puede tipificar el delito de conducta monopólica, por la naturaleza dinámica de las conductas anticompetitivas. Además, se dijo que la normativa penal no ha funcionado como un buen inhibidor de conductas anticompetitivas, porque prácticamente nunca se ha recurrido a la acción penal," ${ }^{87}$ lo cual fue aprobado en general por los Senadores concurrentes. Al pasar a discutirse el Proyecto en la Comisión de Hacienda del Senado, el entonces Subfiscal Nacional Económico, don Enrique Vergara, reiteró que en él "se eliminan las penas privativas de libertad que consagra la actual legislación, por dos razones, la primera, jurídica, ya que se ha estimado que esta norma contenía una ley penal en blanco, y, otra, práctica, puesto que en los últimos treinta años nunca se ha aplicado esta norma." ${ }^{\text {" }} \mathrm{Al}$ pasar el Proyecto a discutirse en la Cámara de Diputados, en su comparecencia ante las Comisiones Unidas de Constitución, Legislación y Justicia y de Economía, Fomento y Desarrollo, don Jorge Streeter Prieto, abogado, profesor de Derecho Económico de la Universidad de Chile, señaló, reafirmando lo sostenido por el Mensaje, que "en el caso chileno y desde el punto de vista penal, el llamado delito de monopolio ha sido enteramente ineficaz y nunca nadie ha sido castigado por cometerlo", agregando que "ello no se debía a que jamás se hubiera incurrido en una conducta monopólica o en una colusión ilícita, sino que al hecho de que los órganos del Estado llamados a aplicar la ley, nunca han estimado del caso tratarla como una verdadera ley penal, considerándola como propia del ámbito económico, en que incluso las infracciones más graves, no merecen la sanción prevista en la ley.", 89

A partir de este momento no se hizo mayor cuestión, durante la tramitación parlamentaria, de la despenalización de las conductas contrarias a la libre competencia que el Proyecto de ley proponía sancionar de manera exclusiva por la vía administrativa, en un procedimiento especial a cargo de la Fiscalía Nacional Económica y el Tribunal de la Libre Competencia que se creó con la entrada en vigor de la Ley $\mathrm{N}^{\circ} 19.911$.

Por lo tanto, no cabe sino concluir que nuestro Congreso Nacional hizo suyos los planteamientos del Mensaje Presidencial correspondiente, despenalizando de manera total y absoluta las conductas que pudieran calificarse de contrarias a la libre competencia y, en particular, las ejemplificadas en el artículo $3^{\circ}$ letra a) del decreto Ley $\mathrm{N}^{\mathbf{0}} 211$, a saber, "acuerdos expresos o tácitos entre agentes económicos, o las prácticas concertadas entre ellos, que tengan por objeto precios de venta o de compra, limitar la producción o asignarse zonas o cuotas de mercado", pues, en conformidad con la actual redacción del inciso segundo del artículo $1^{\circ}$ de este cuerpo legal, "los atentados contra la libre competencia en

\footnotetext{
${ }^{86}$ Biblioteca del Congreso Nacional, Historia, cit. nota $\mathrm{n}^{\circ}$ 8, p. 32.

${ }^{87}$ Biblioteca del Congreso Nacional, Historia, cit. nota $n^{\circ} 8$, p. 53.

${ }^{88}$ Biblioteca del Congreso Nacional, Historia, cit. nota $n^{\circ} 8$, p. 246.

${ }^{89}$ Biblioteca del Congreso Nacional, Historia, cit. nota $\mathrm{n}^{\circ}$ 8, p. 321.
} 
Polít. crim. Vol. 8, № 15 (Julio 2013), Doc. 1, pp. 314 - 362.

[http://www.politicacriminal.cl/Vol_08/n_15/Vol8N15D1.pdf]

las actividades económicas serán corregidos, prohibidos o reprimidos en la forma y con las sanciones previstas en esta ley", la cual no contempla para ellos sanciones penales de ninguna especie.

2.4.3. La situación legal tras la despenalización de las conductas atentatorias contra la libre competencia, de conformidad con la Ley $\mathrm{N}^{\circ}$ 19.911, de 14 de noviembre de 2003. La incompatibilidad absoluta de la despenalización con la aplicación del Artículo 285 Código penal y la consecuente prohibición de su supuesto "resurgimiento".

De conformidad con lo antes explicado, la historia fidedigna del establecimiento de la Ley $\mathrm{N}^{\mathrm{o}} 19.911$ y las modificaciones que introdujo al Decreto Ley $\mathrm{N}^{\mathrm{o}} 211$ indican su inequívoco propósito de despenalizar las conductas atentatorias contra la libre competencia, entregando su prevención y sanción a los organismos administrativos que allí se establecen.

Por lo tanto, en este caso se produce una incompatibilidad absoluta entre la Ley $\mathrm{N}^{\mathrm{o}} 19.911$, de 2003, posterior y especial, que despenaliza expresamente los atentados a la libre competencia y las conductas monopólicas en general, y el artículo 285 del Código penal de 1874, si se entendiera para efectos retóricos que éste penalizaba desde el siglo XIX dichas conductas como una forma de alteración fraudulenta de los precios naturales de las mercancías.

Esta incompatibilidad absoluta entre una ley posterior y especial (el Decreto Ley $\mathrm{N}^{\mathrm{o}} 211$, de 1974, reformado por la Ley $\mathrm{N}^{\circ}$ 19.911, de 2003) y otra anterior (el artículo 285 del Código penal de 1874), produciría de por sí el efecto de derogar tácitamente la ley anterior, si se llegase a afirmar que ésta, a pesar de lo dicho anteriormente, de todos modos continuaba vigente en el año 2003, sancionando penalmente los acuerdos de precios entre proveedores, hechos que el legislador de 2003 indubitablemente ha querido sustraer de la jurisdicción criminal. De este modo, el supuesto "resurgimiento" del Art. 285 del Código penal pasaría a pasar a llevar no sólo los expresos privilegios procesales y sancionatorios concedidos, sino el propio principio de legalidad, al aplicarse una pena a un hecho expresamente exento de la misma.

Por otra parte, en la nueva redacción que se ha dado al Decreto Ley № 211 de 1974, se ha suprimido su anterior artículo $5^{\circ}$, que mantenía en vigor ciertas disposiciones (pero no el artículo 285 del Código penal), agregándose un nuevo artículo $5^{\circ}$ transitorio que dispone:

“Artículo 5.- Deróganse las disposiciones del Título V de la ley Nº13.305.

Declárase que las conductas comprendidas en los hechos constitutivos de delito con arreglo a lo establecido en los artículos $1^{\circ}, 2^{\circ}$ y $3^{\circ}$ de esta ley, según el texto original del decreto ley $\mathrm{N}^{\circ} 211$, de 1973 , realizadas con anterioridad a la vigencia del citado cuerpo legal, no serán susceptibles de ser sancionadas en conformidad con lo expresado en los referidos preceptos, ni, tampoco, de acuerdo a lo que estatuía el Título V de la ley $\mathrm{N}^{\circ} 13.305$, derogado por el inciso anterior de este artículo, sin perjuicio de lo dispuesto en el artículo $1^{\circ}$ transitorio."

Es decir, se establece expresamente un privilegio para las conductas monopolísticas y otros atentados contra la libre competencia, entendidos anteriormente como delitos por la Ley $\mathrm{N}^{\circ}$ 
MATUS, Jean Pierre "De nuevo sobre la falta de punibilidad de los atentados contra la libre competencia, de conformidad con el Art. 285 del Código penal. Algunos aspectos de la discusión con Héctor Hernández en Política Criminal"

13.305 y el Decreto Ley No 211 de 1974, según el cual, éstos ya no son delitos, esto es, no pueden ser sancionados penalmente, sino sólo administrativamente.

\section{Conclusiones.}

3.1. El bien jurídico protegido en el Art. 285 del Código penal es la libre concurrencia de oferentes y demandantes en un mercado determinado, no la libre competencia entre unos y otros, tal como demuestra la historia fidedigna de la ley y lo entendió y entiende hasta hoy en día la mejor doctrina nacional;

3.2. En consecuencia, los artículos 285 y 286 del Código penal vigente no castigan las "coligaciones" o acuerdos de precios libremente alcanzados entre oferentes o demandantes de trabajo o mercaderías, incluso las de primera necesidad, acuerdos que se estiman lícitos, como "ejercicio de un derecho", esto es, la libertad de contratación, y no pueden considerarse medios fraudulentos para conseguir la alteración de su precio natural;

3.3. El precio natural del trabajo y otros objetos de contratación es el que resulta de la libre concurrencia entre oferentes y demandantes en un mercado determinado, sin la mediación de un fraude que afecte la inteligencia de todos ellos acerca de las condiciones que han de tomarse en cuenta en la fijación del precio (básicamente, la escasez o disponibilidad del objeto de contratación o las condiciones que permitirían traerlo a un mercado determinado);

3.4. La noción de justo precio, contemplada en el Art. 1.889 del Código civil no es en principio equivalente a la de precio natural del Art. 285 del Código penal, pues la idea del justo precio corresponde a un resabio histórico escolástico de alguna manera incompatible con la de libertad de contratación y en la regulación civil sólo es aplicable a las transacciones sobre bienes inmuebles. Sólo se asimila justo precio a valor de cambio o precio de mercado podrían de algún modo superarse esas contradicciones;

3.5. Al redactarse el Código penal, en 1874, se entendió explícitamente que, en casos de "coligaciones" o acuerdos de precios entre oferentes, considerados como una forma lícita de fijación de precios, el correctivo que existía no era el Derecho penal, sino la libertad de industria, esto es, la inexistencia de trabas estatales al emprendimiento individual;

3.6. Las disposiciones de los Arts. 52 y 53 de la Ley de Mercado de Valores, en relación con su Art. 59 letra e) no son una lex specialis frente a Art. 285 del Código penal, sino que se encuentran en relación de subsidiariedad tácita respecto a los atentados contra la libre concurrencia en el mercado de acciones y otros valores regulados por dicha ley;

3.7. Sólo con la entrada en vigor de la Ley $\mathrm{N}^{\mathrm{o}} 13.305$, de 1959, los acuerdos de precios y otras conductas monopolísticas pasaron a ser sancionados como hechos ilícitos, los cuales hoy se encuentran nuevamente despenalizados y sancionados solo administrativamente, exclusivamente en el Decreto Ley No 211, de 1974; 
Polít. crim. Vol. 8, № 15 (Julio 2013), Doc. 1, pp. 314 - 362.

[http://www.politicacriminal.cl/Vol_08/n_15/Vol8N15D1.pdf]

3.8. De aceptarse la interpretación del Art. 285 del Código penal de Héctor Hernández, y aplicarse hoy en día a supuestos de atentados a la libre competencia regulados en el D.L. No 211 de 1974, se estaría aplicando a tal caso de una norma penal derogada, lo cual resultaría contrario a lo preceptuado por el artículo $19 \mathrm{~N}^{\circ} 3$, inciso $8^{\circ}$ de la Constitución, que impone la exigencia de que sólo pueden ser punibles los hechos que han sido establecidos como delitos por una ley que se encuentre vigente como tal, promulgada con anterioridad a su perpetración.

En efecto, de considerarse que el Art. 285 del Código penal de 1874 reguló en algún momento del siglo XIX y hasta la mitad del siglo XX tales conductas, lo cierto es que, en ese aspecto, dicha disposición habría sido tácita y parcialmente derogada por las disposiciones del Título V de la Ley $\mathrm{N}^{\circ}$ 13.305, de 6 de abril de 1959, cuyas disposiciones penales (recogidas en el Decreto Ley $\mathrm{N}^{\circ} 211$ de 1974) fueron también derogadas posteriormente, por la Ley No 19.911 de 14 de noviembre de 2006.

Y esta absoluta, expresa y consciente despenalización de las conductas por la Ley $\mathrm{N}^{\mathrm{o}}$ 19.911, de 2003, es absolutamente incompatible con la pretensión de que ello signifique al mismo tiempo su penalización por una norma del siglo XIX, lo cual es en general contrario al fundamento del principio de legalidad, en orden a la previsibilidad de la respuesta del Estado a las conductas de los ciudadanos y, en particular, a la teoría del "resurgimiento de la ley desplazada", que no lo admite cuando con ello se lleva a pasar la voluntad claramente manifestada por el legislador de despenalizar o establecer un privilegio. 